J. EMLEN MYERS

FERNANDO DE AMORES CARREDANO

JACQUELINE S. OLIN

ALFONSO PLEGUEZUELO HERNÁNDEZ

\section{Compositional Identification of Seville Majolica at Overseas Sites}

\section{ABSTRACT}

This study reports compositional data for the first majolica ceramics excavated from a 16th-century kiln site in the Sevillian suburb of Triana. Instrumental neutron activation analysis (INAA) of 63 of the ceramics provides baseline data for documenting the growth and spread of Spanish majolica industries and networks of supply during the Spanish colonial period. In an initial comparison the kiln site data are shown to match majolica data from the North African Portuguese fort of Qsar es-Seghir (1458-1550) and the New World Spanish mission of Santa Catalina de Guale (1567-1680), confirming that Seville majolica was exported to both settlements. The Santa Catalina samples are from more than one source, however, and some are compositionally unrelated to any Spanish data. Two alternative hypotheses are offered to explain the difference in supply at the two colonies.

\section{Introduction}

Majolica, like faience and delft, is an earthenware ceramic, usually of a calcareous clay, covered with a tin-opacified lead glaze (Caiger-Smith 1973; Hamer 1975:190-193). It was produced by a technique of Middle Eastern origin that came to be used throughout Europe and the colonies. Its tin glaze creates an opaque white surface on which glaze painted designs are highlighted. Bluepainted majolica gave the effect of Oriental porcelain and was often used as a substitute for it (Caiger-Smith 1973:43, 87). Beginning in late-medieval times Spanish majolica tableware was exported to England (Hurst 1977:68-105), the Netherlands (Hurst 1986:347-351), Italy (Berti and Tongiorgi 1985), and North Africa (Boone 1984: 76-86), as well as to the Spanish colonies of the New World (Goggin 1968). Although it is found archaeologically in the western Mediterranean and
Northern Europe, common Spanish majolica export ware was in fact first intensively investigated by New World archaeologists. John Goggin began this research in the late 1940s, working at Spanish colonial sites in the Southeastern United States and the Caribbean. His comprehensive study of Spanish majolica in the Americas was published in 1968 , and, with the modifications of the Listers (1974, 1982), Deagan (1987), and others, the work still stands today as the definitive typology of Spanish export majolica. More recently petrographic and chemical data have also played a role in the study of majolica of the Spanish colonial period (Olin et al. 1978; Maggetti et al. 1984; Olin and Blackman 1989).

The Morisco wares (Lister and Lister 1982:4557), the primary focus of this paper, form a complex of plain and painted common tableware majolica types that probably account for the majority of the majolica exported from Spain to the New World from the late 15 th through the 16th centuries. The Andalusian town of Seville was the administrative center for Spain's overseas activities, and its port of Triana is believed to have been the source of most of the majolica, including Morisco ware, exported to the New World through the 18th century. Nonetheless smaller quantities of majolica from Talavera and Manises appear to have been shipped to the New World as well (Lister and Lister 1982:68, 1987:160). For Morisco ware, the hypothesis of Sevillian origin was adopted by Goggin based on three lines of evidence: (1) its presence in the paintings of Sevillian artists, (2) its abundance in undocumented archaeological collections in Seville, and (3) documentary references to the shipment of tableware from Seville and Triana to the New World (Goggin 1968:124-126). Subsequent chemical analyses indicated a related source for Morisco wares found in the Caribbean and sherds of Sevillian type found at the Andalusian town of Jerez de la Frontera (Olin et al. 1978: 216). This evidence along with additional typological comparisons of Old and New World finds led to a further strengthening of the "Seville Hypothesis" in the literature (Lister and Lister 1982:45).

New archaeological and compositional data in this paper allow the characterization of Morisco 
ware sources in Seville. This, in turn, provides a basis for refining majolica typologies based on the correspondence of visual attributes of the ceramics with the compositional source groups being defined. The purpose of the larger project is to develop majolica typology as an archaeological tool for studying Spanish and Spanish colonial supply and commerce through the identification of majolica sources represented at different Spanish colonial sites.

\section{Compositional Method for Characterizing Majolica Sources}

This study employs instrumental neutron activation analysis (INAA), a sensitive technique of chemical analysis that requires relatively little sample preparation and provides precise data for up to 35 elements (Perlman and Asaro 1969; Harbottle 1976). The analyses for this project are being conducted at the Smithsonian Institution's facility at the National Institute of Standards and Technology following procedures described by Blackman et al. (1989). Only the fired clay portion of an artifact is sampled for analysis.

The method of data interpretation employs the elemental composition of the samples to define chemically homogeneous groups of artifacts, the assumption being that the differences between the groups are the result of different characteristic local clays and/or different treatment of clays during manufacture (Bishop et al. 1982; Harbottle 1982; Bishop and Neff 1989). This method often provides great interpretive value in the simple compositional grouping of artifacts, as is illustrated below. The geographical origin of a group, however, is most securely determined with data from archaeologically documented samples. Since compositional studies of Spanish majolica have suffered from a lack of data from excavated samples, a major focus of recent efforts has been the acquisition and analysis of excavated samples from majolica production sites.

In an earlier study Olin et al. (1978:216) found that concentrations of the trace elements lanthanum, cerium, and thorium distinguish majolica types of presumed Spanish origin from Spanishstyle types of presumed New World origin, the Spanish types having significantly higher concentrations of all three elements. This discovery tended to confirm the value of the Goggin typology but provided a valuable refinement as well. A plain white majolica excavated in Mexico City was originally thought to have come from Seville and had been classified as Columbia Plain. On analysis its composition proved to be Mexican (Olin et al. 1978:207), providing a basis for its designation by the new type-name Mexico City White (Lister and Lister 1982:22).

More recently Olin and Blackman (1989) analyzed majolica samples from another New World Spanish site, that of Santa Catalina de Guale (Thomas 1988:73-146). The sampled sherds were classified by the site's excavators according to Goggin's (1968) and the Listers' (1982) criteria (Debra Peter 1986, pers. comm.), allowing them to be grouped according to presumed Old or New World origin as shown in Table 1. Data for the typologically Old World samples identified in the table are given in Appendix A. Data for all of the samples identified in Table 1 are published in Olin and Blackman (1989).

From the attributions of the types listed in Table 1 , one would expect the two typological groups to have characteristically different lanthanum, cerium, and thorium concentrations. The bivariate plot of the concentrations of cerium and thorium in Figure 1 shows this to be so. The ellipses around each of the two clusters in the plot coincide with the 95 percent confidence limit for each of the two populations from which the samples were taken. Confidence limits are calculated with Mahalanobis distance and Hotelling's $\mathrm{T}^{2}$ statistic. The nonoverlapping ellipses and the small number of samples outside the ellipses (only two) represent an agreement of two independent means of ceramic classification, one visual and one compositional, further evidence for Olin's (Olin et al. 1978) compositional distinction between Old and New World majolica. As is evident in the spread of the data, however, there is significant chemical variability among the "Old World Types" shown in Figure 1.

Given the objective of verifying the provenance 
TABLE 1

TYPOLOGY OF SAMPLES FROM SANTA

CATALINA DE GUALE

Type

New World Group

San Luís Blue on White (Mexican variant)

Aucilla Polychrome

San Juan Polychrome

Mt. Royal Polychrome

Puebla Polychrome

Puebla Blue on White

Total

Quantity

Old World Group

Columbia Plain

Yayal Blue on White

San Luis Blue on White (Spanish variant)

Ichtucknee Blue on Blue

Santo Domingo Blue on White

Sevilla Blue on White

Santa Elena Mottled Blue on White

Unclassified Blue on White

Montelupo Polychrome

Total

of the Spanish export wares it is necessary to establish whether or not the products of majolica centers within Spain can also be distinguished compositionally. For this purpose majolica samples have been analyzed from the production centers of Seville, Talavera, and Manises shown on the map in Figure 2 (Jornet et al. 1985a, 1985b; Amores et al. 1988; McEwan 1988:120, 171). Sample selection could not be guided by rigorous criteria for all of these ceramics since the archaeology of Spanish colonial period Talavera and Manises is not yet well developed. Nevertheless, if the products of these centers can be distinguished by their chemical composition, then a trial grouping of the samples by find site should bear this out. Figure 3 illustrates the finding that there is in fact a compositional difference between the groups. A bivariate comparison using elements scandium and thorium readily differentiates the majolica found at the three centers. A similar pattern of separation

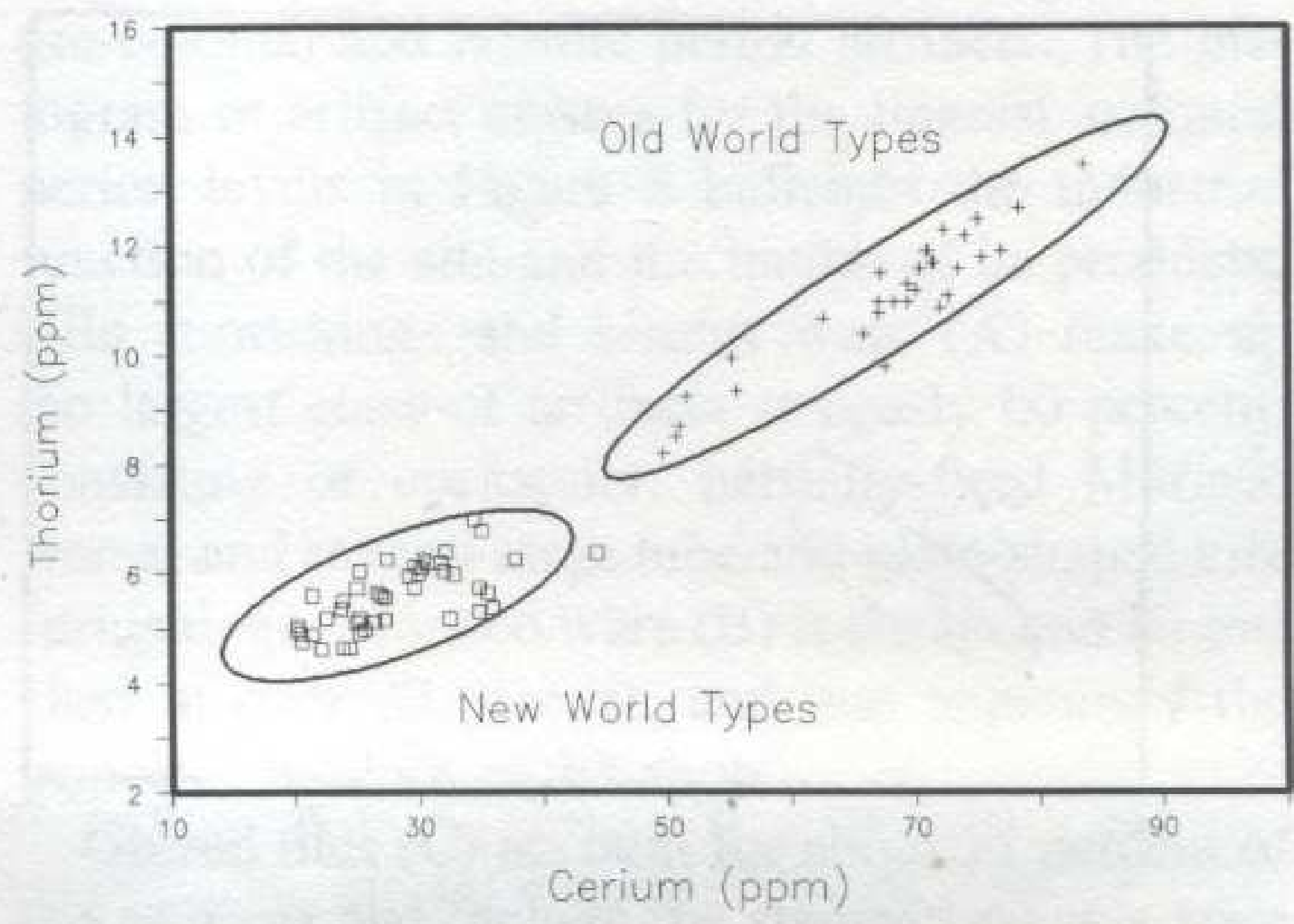

FIGURE 1 . Thorium vs. cerium plot for typologically attributed Spanish and Mexican Majolica excavated at Santa Catalina de Guale (see Table 1).

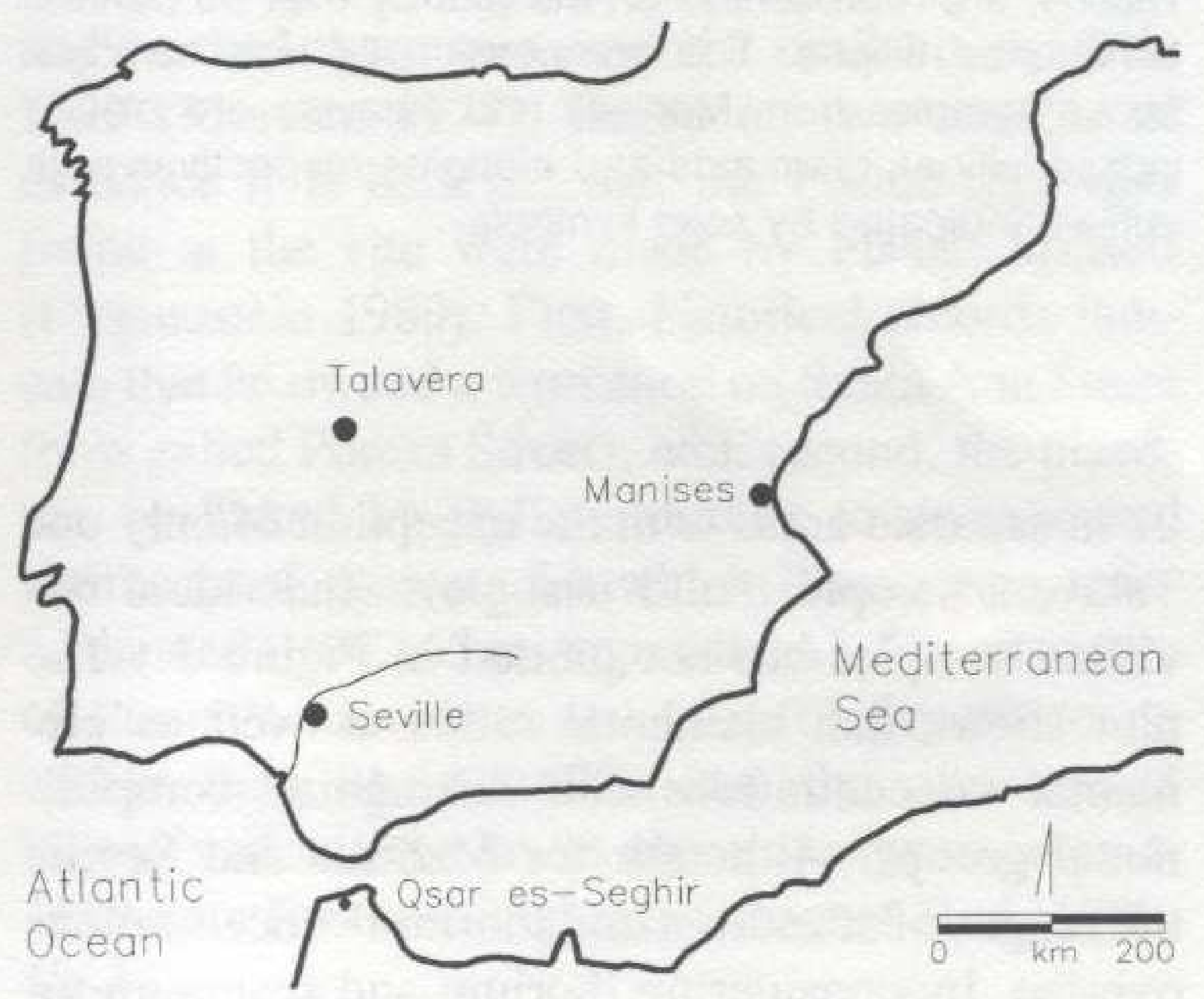

FIGURE 2. Map of western Mediterranean indicating locations of the three Spanish majolica production centers and the Moroccan site of Qsar es-Seghir.

was also seen in a variety of bivariate plots of the elements scandium, lanthanum, cerium, samarium, and thorium. The 95 percent confidence ellipse for the Seville group is based on 63 samples from the Pureza Street kiln site and 56 samples from a number of other 16th- and 17th-century sites in Seville. The ellipse excludes all other samples with the exception of one from Manises (solid diamond). Also the Manises and Talavera samples 


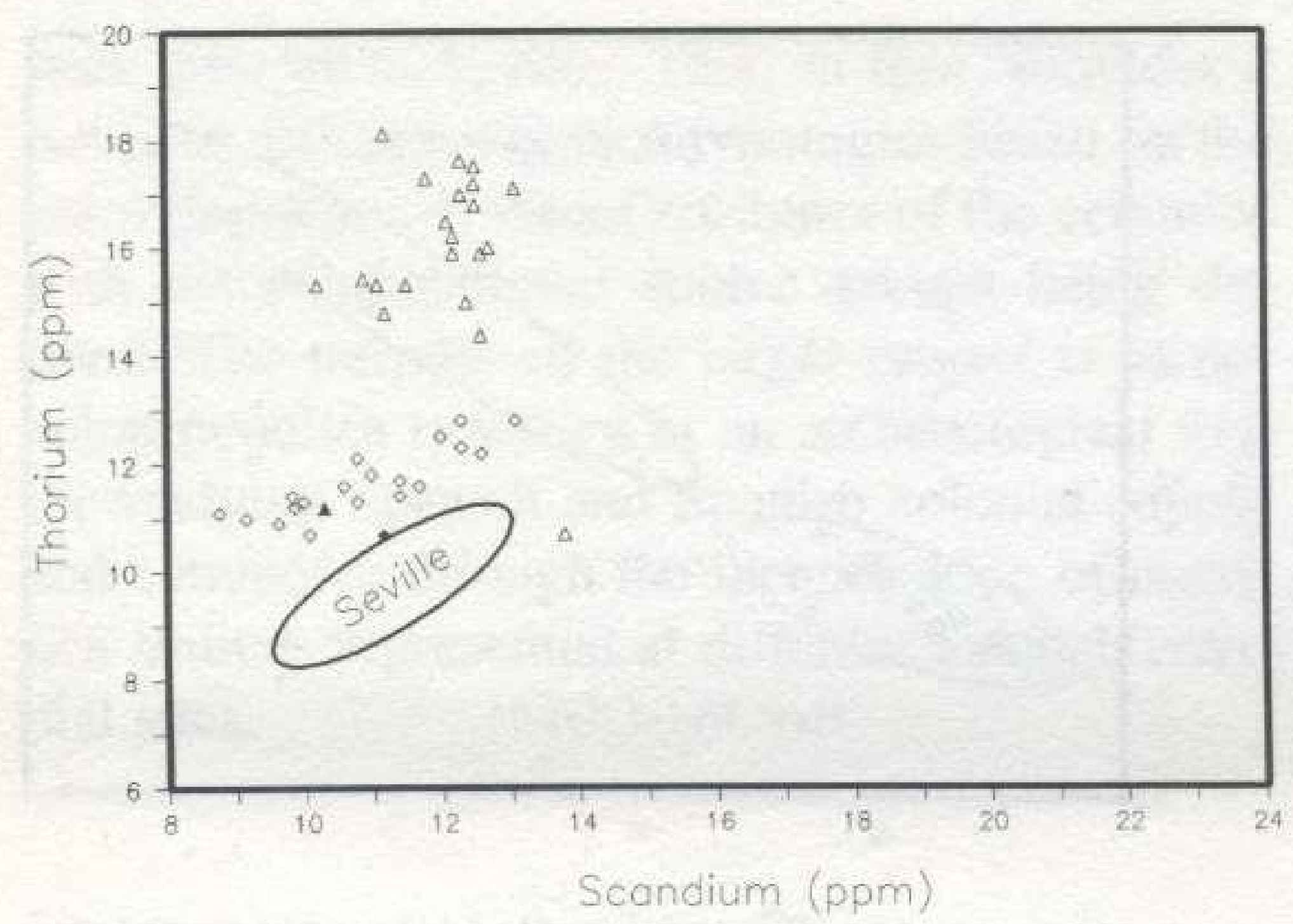

FIGURE 3. Thorium vs. scandium plot for samples of majolica found at the three Spanish production centers of Seville, Manises, and Talavera. The 119 Seville samples, which include artifacts from the kiln site and other excavations, are represented on the plot by their 95 percent confidence ellipse. The compositionally less homogeneous samples from Manises and Talavera are plotted individually as diamonds and triangles respectively with outliers indicated by solid symbols.

lie in separate areas with the exception of only one Talavera sample (solid triangle). (Individual Sevillian samples are not plotted in Figure 3.) The plot shows that elemental ratios as well as elemental concentrations can distinguish compositional groups. Although for Manises and Seville the ranges of scandium and thorium concentrations overlap, by considering thorium and scandium together the two groups can be separated. The bivariate separation is a consequence of the different patterns of scandium/thorium correlation within each of the two groups. The two groups of samples lie along different lines.

Comparison of production centers based on samples found at Seville, Manises, and Talavera has been useful in indicating that there are significant compositional differences between majolica presumed to have been made at these centers. Two issues remain however regarding the Talavera and Manises samples (Jornet et al. 1985a:238). First, it would be preferable to characterize the composition of the production centers based on artifacts from documented excavations. Second, in view of

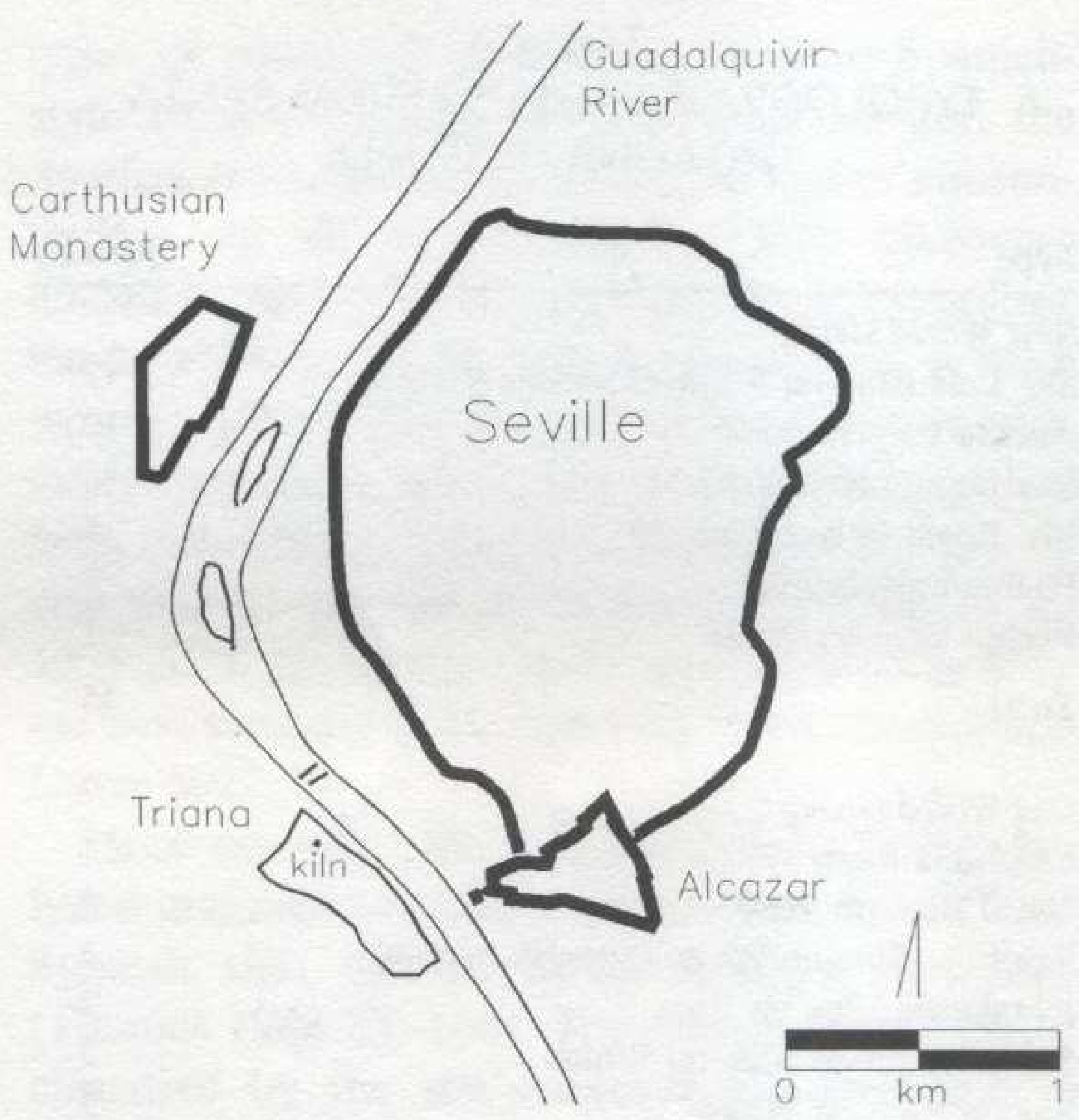

FIGURE 4. Map of 16 th-century Seville indicating the locations of Triana and the kiln site.

the small sample size from these centers it is uncertain whether the outliers in Figure 3 represent other compositionally distinct groups from the presumed production centers, or imports from another source. Both issues await additional archaeological and compositional research on Manises and Talavera ceramics.

\section{Archaeological Evidence of Seville Majolica Production}

In the case of Seville, recent excavations have provided archaeological data on 16th-century majolica industries. The city currently maintains a program of rescue archaeology in its historic district, which has included the suburb of Triana since 1986 (Figure 4). As part of this program Lorenzo and Vera (1987:574-580) made the first excavations in Triana at the instigation of Amores in the winter of 1986. The excavations revealed part of a ceramic workshop and kiln at 44 Pureza Street, providing artifacts for a preliminary compositional 


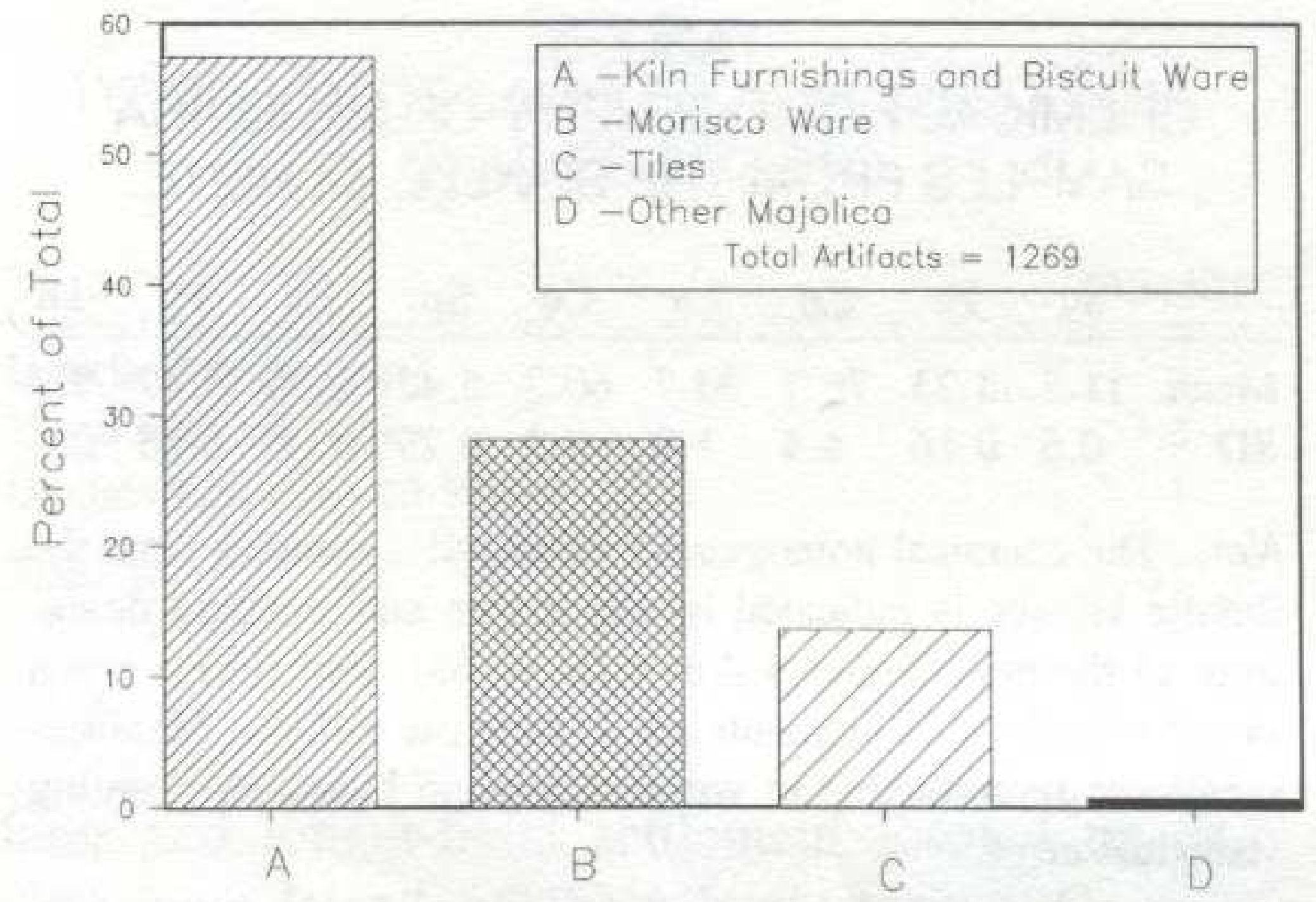

FIGURE 5. Frequency of four classes of ceramic artifacts excavated at the Pureza Street kiln site.

study (Amores et al. 1988). The largest component of the site dates to ca. 1500-1600 based on the ceramic types present (Amores et al. 1988:12-13). This component includes a layer of fill that was deposited over a much shorter period of time in the bottom of a ruined kiln. The deposit was most probably laid down in order to level the workshop area shortly after the kiln was dismantled. Based on stylistic parallels with ceramics found in the fill, the leveling operation took place some time in the first quarter of the 16th century. Sixteenthcentury Triana is known to have been a majolica production center with as many as 30 active kilns (Lister and Lister 1987:160). The kiln site found at 44 Pureza Street was thus only one of many such workshops. Property boundaries as well as street names and addresses in Triana have changed since the 16th century so it is probable that the excavated site does not correspond precisely to the shop to which the kiln belonged. Although no other kilns have been found, the kiln furnishings and early 16th-century pottery dumped into the kiln were not necessarily fired in it. The later 16th-century majolica and the 17th- through 18th-century majolica excavated at the site must have been fired elsewhere, probably in kilns that are now buried beneath adjacent modern buildings.

Over 3,000 ceramic artifacts were found at the Pureza Street site, including a sizeable quantity of pre-colonial and Islamic period artifacts. The histogram of artifact classes for the Spanish colonial period levels in Figure 5 indicates the industrial function of the site and the nature of its products. Kiln furnishings and biscuit ware (A) make up the largest class of artifacts at nearly 60 percent, consisting of cockspurs, partially-fired Morisco wares, and several large tube and plate-shaped kiln furnishings. Morisco ware (B) is the second largest class at over 20 percent, and was apparently the principal product of the shop.

Glazed tiles (C) account for about 15 percent of the artifacts and include the stamped cuenca style and the flat painted Pisano style, with cuenca in the majority. Pisano tiles were first made in Spain in the first decade of the 16th century by Francisco Niculoso Pisano who came to Seville in the 1490s and worked there as a ceramist until his death in 1529 (Morales 1977). Based on two sources of evidence it is believed that the Pisano-type tiles found at the site were made by Pisano himself (Pleguezuelo 1989). First, historical records indicate that he owned a workshop on Santa Ana Street (now called Pureza Street), and, second, the pieces can be linked by stylistic criteria to documented architectural projects for which Pisano was commissioned (PUZ165 in Appendix A). The presence of Pisano's tiles dates the kiln fill deposit to no earlier than about 1509, and the absence of Pisano's tiles in the layers above it suggests a post1529 date for those deposits (Amores et al. 1988: 12-13).

Finally, a mixed group of non-Morisco ware majolica types (D) accounts for the remaining 1 percent of the ceramics. Two of the artifacts are fused plates (PU0051 and PU0073) of the 17ththrough 18th-century type called Seville Delft-like that were found very near the surface of the site (McEwan 1988:429; Solís 1988:130). Two others are tiles (PU1230 and PU1250) of Caparra Blue, and another is a glazed terra-cotta Christ figurine (PU2024).

To summarize, the workshop was functioning as a producer of Morisco ware majolica in the 16th century, and the same workshop, or a neighboring one, continued producing majolica until as late as the 18 th century. 
TABLE 2

TYPOLOGY OF SAMPLES FROM SEVILLE KILN SITE AT 44 PUREZA STREET

Type Quantity

Isabela Polychrome

21

Columbia Plain

Yayal Blue on White

Santa Elena Mottled Blue on White

Santo Domingo Blue on White

Caparra Blue (tile)

Pisano Tile

Seville Delft-like

Unclassified Blue on White

White-glazed Figurine

Biscuitware Wasters

Cockspurs

Total

16

5

3

3

2

1

2

3

1

2

4

63

\section{A Compositionally Defined Source for Seville Majolica}

In order to establish a compositional baseline for comparisons with majolica from colonial sites, 63 ceramic samples from the Pureza Street site were analyzed. These include 16 samples from the early 16th-century fill layer of the kiln and 47 dating primarily from later 16th-century contexts. (Although other Seville samples were included along with the Pureza Street samples in Figure 3, they are from less controlled archaeological contexts.) Chemical data and typological identification of the 63 source samples are given in Appendix A, and a typological summary of the samples is given in Table 2.

Table 3 contains the group elemental concentrations of the Pureza Street artifacts, data that indicate a very consistent composition. One standard deviation is 6 percent of the mean or less for the nine elements, a degree of homogeneity that justifies considering the group as a compositional source. This uniformity of composition confirms that all members of the group, not just the wasters and kiln furnishings, belong to the same production source. As shown in Table 2 the Pureza Street group includes 15 samples of non-Morisco ware ceramics, indicating considerable typological vari-
TABLE 3

CHEMICAL HOMOGENEITY OF MAJOLICA SAMPLES FROM THE SEVILLE KILNSITE

\begin{tabular}{lrrrrrrrrr} 
& \multicolumn{1}{c}{$\mathrm{Sc}$} & $\mathrm{Fe}$ & $\mathrm{Zn}$ & $\mathrm{La}$ & $\mathrm{Ce}$ & $\mathrm{Sm}$ & $\mathrm{Eu}$ & $\mathrm{Hf}$ & $\mathrm{Th}$ \\
\hline Mean & 11.2 & 3.23 & 76.7 & 34.7 & 60.2 & 5.42 & 1.06 & 5.47 & 9.7 \\
SD & 0.6 & 0.16 & 4.4 & 1.9 & 3.2 & 0.29 & 0.06 & 0.35 & 0.6
\end{tabular}

Note. The chemical homogeneity of majolica samples from the Seville kilnsite is indicated by the means and standard deviations of the nine elements shown $(\mathrm{N}=63)$. Iron $(\mathrm{Fe})$ is given in percent; all other elements are in parts per million. Measurements are reproducible to within 1 percent based on counting statistical error.

ation in the ceramics produced by the shop. Also, the 17th- to 18th-century date of the two Seville Delft-like pieces, which are compositionally indistinguishable from the Morisco wares and kiln furnishings, suggests that this source underwent little if any compositional change over time. If this pattern proves to be generally true for Seville's majolica production of the Spanish colonial period then the problem of identifying Seville and nonSeville majolica at overseas sites would be resolved. This potentially very significant finding will be examined in current research which includes the analysis of later Spanish colonial period majolica types from Sevillian archaeological contexts.

The Seville Source Compared with Majolica at Overseas Sites

Comparable chemical data for majolica exist for two overseas sites presumed to have been supplied from Spain. The first site is the North African Portuguese fort of Qsar es-Seghir (1458-1550). Documentary evidence indicates that the Portuguese soldiers at the fort were receiving supplies from Spanish ports (Boone 1980:121). The typology of the samples (Table 4) also indicates that the majority of the majolica used there was probably of Spanish origin (Boone 1984; Redman 1986; Sinopoli n.d.). The second site is the previously discussed mission of Santa Catalina de Guale (1567-1680), a 
TABLE 4

TYPOLOGY OF SAMPLES ANALYZED FROM QSAR ES-SEGHIR

Type

Isabela Polychrome

Yayal Blue on White

Unclassified Blue on White

Total

Quantity

8

2

1

11

later and longer-lived settlement located on St. Catherines Island, off the Atlantic coast of Georgia (Thomas 1988:73-146). Although the Santa Catalina samples include both the Old and New World types in Figure 1 and Table 1, this article is concerned only with the presumed Old World types. More than half of these are Morisco ware including Columbia Plain and Yayal Blue on White, with the remainder consisting of later, related types.

Figure 6 illustrates the compositional relationship of the Qsar es-Seghir and Santa Catalina de Guale samples with the Seville source group. A similar pattern of separation was also seen in a variety of bivariate plots of the elements scandium, lanthanum, cerium, samarium, and thorium. Since Manises and Talavera were important majolica production centers, the ranges of values for those samples are indicated as well. In Figure 3 it was seen that the Manises and Talavera sources were distinct from each other and from Seville. In Figure 6 it can also be seen that the overseas samples are largely distinct from the Manises and Talavera sources. A total of three Santa Catalina de Guale and Qsar es-Seghir samples lie within the dashed area for Manises. More important is the fact that the majority of the Qsar es-Seghir samples fall within the Pureza Street confidence ellipse while only five of the 32 Santa Catalina Spanish samples do. Also, unlike the Santa Catalina samples that are close to the Seville source, the Qsar es-Seghir samples are evenly distributed in a cluster that stretches from the lower end of the ellipse to just outside its upper boundary. This pattern is further evidence of a much closer relationship between these Qsar es-Seghir majolica samples and the Seville source group.

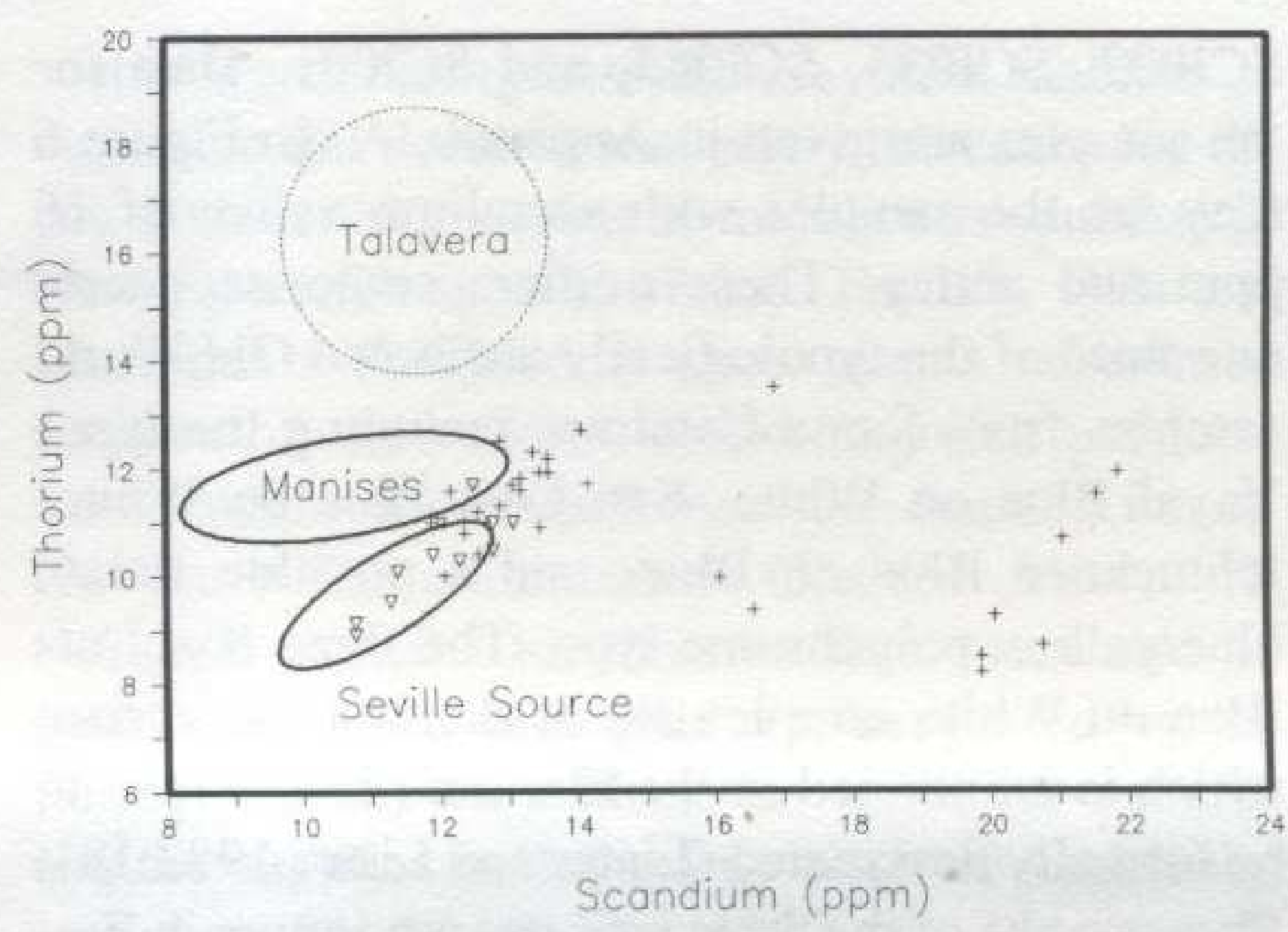

FIGURE 6. Thorium vs. scandium plot of majolica groups from Seville, Manises, and Talavera compared with Santa Catalina de Guale "Old World" samples (crosses) and Qsar es-Seghir samples (triangles). The solid enclosures mark the 95 percent confidence ellipses for the Seville and Manises sources. The dotted enclosure marks the extent and approximate shape of the distribution of the Talavera samples. Probability ellipses were not used for these samples due to the uncertainty of their context and inhomogeneity in their composition.

The 20 Santa Catalina samples closest to the Seville source group straddle the upper boundary of the ellipse with some inside it and most outside of it. Nearly all, however, have scandium/thorium ratios similar to the Seville group. A number of factors could contribute to such differences among ceramics from a single locale, one possibility being the blending of clays. It is known that a blend of clays has been used in Seville both from descriptions of the clays used for majolica in recent times (Gonzales and Garcia 1966) and from petrographic examination of archaeological majolica from the region (Jornet et al. 1985a). Although it is not apparent precisely how the observed differences could have been produced by blending, it is believed that these Santa Catalina sherds are related to the Seville source.

In view of the expectation that the Spanish colonies received the majority of their tableware from Sevillian industries, the 10 Santa Catalina ceramics that lie well away from the Seville group are particularly interesting. They are samples SCI042, SCI052, SCI075, SCI002, SCI003, SCI004, 
SCI007, SCI033, SCI065, and SCI061. Data for the samples are given in Appendix A. In Figure 6 they are the samples with scandium values of 16 ppm and above. These outliers comprise nearly one-third of the typologically attributed Old World samples from Santa Catalina, including the types Yayal Blue on White, San Luís Blue on White, Ichtucknee Blue on Blue, and a possible Italian blue/yellow polychrome type. The three San Luís Blue on White samples are of the Spanish variant which is mentioned in the literature but has yet to be formally designated (Lister and Lister 1982:18). Photographs of the three artifacts are shown in Figure 2 in Olin and Blackman (1989). The three do not match any of the other Spanish groups in this database. The probability that these apparently non-Spanish ceramics found at Santa Catalina de Guale are simply 17 th-century Sevillian wares is diminished by the fact that two post-16th-century sherds (PU0051 and PU0073) excavated at the Pureza Street kiln site have compositions that are not significantly different from the 16th-century samples from the kiln site. There are four Yayal Blue on White samples among the outliers (SCI002, SCI003, SCI004, and SCI007), and these likewise cannot be matched with the Seville source group or with any of the other Old World sources. A published whole vessel found in Seville and identified as a 16th-century Triana product is stylistically very similar to the small Yayal Blue on White sherds in question (Pleguezuelo 1985:73, \#20). The rim decoration on the sherds, however, is also similar to that of a vessel shown in a photograph by Deagan $(1987: 111, \mathrm{p} 1.5, \mathrm{~h})$ as an example of the 17th- and 18th-century Blue-Green Basin type which is thought to be of New World origin. Whichever of these two majolica types is the closest parallel for these samples, the uncertainty underscores the looseness of the visual criteria for Yayal Blue on White (cf. Deagan 1987: 58). Even the simple-design variant of this type shows a wide variation in line thickness, in the shade of blue and white color, and in vessel shape and thickness. When sources of these and other variants are compositionally identified, an additional basis will exist for refining the criteria and possibly designating type variants.
One of the two Ichtucknee Blue on Blue samples (SCI033) from among the Santa Catalina de Guale outliers raises questions about the existing typology for blue on blue majolica of the Spanish colonial period. The sample matches very closely the composition of two blue on blue samples (SB30 and SB31) from the Metro excavations in Mexico City (Olin et al. 1978) and also matches the composition of two majolica sherds from Albisola, Italy, analyzed by the British Museum (Michael Hughes 1986, pers. comm.). Initial classification and a re-examination of the two Mexico City blue on blue finds (SB30 and SB31) indicate that they fit the visual characteristics of the Listers' (1982: 72-74) Italian variant of Ichtucknee Blue on Blue (Goggin 1968:135). Not so for the blue on blue sherd (SCI033) in question from Santa Catalina which, despite its Italian composition, is Spanish in appearance (Lister and Lister 1982:44,P; Deagan 1987:108,p1.2,D-G). (The composition of this sherd (SCI033) is also similar to another one of the Santa Catalina outliers (SCI061) which is classified as Montelupo Polychrome, an Italian type.) The other Santa Catalina Ichtucknee Blue on Blue sherd (SCI065) appears to be an example of the Spanish variant as well. Its composition is, however, similar to neither the Seville group nor to SCI033. From these inconsistencies, it is concluded that the defining criteria for the two blue on blue types are in need of any refinement that additional compositional research could bring.

To summarize the source comparisons, the Qsar es-Seghir samples are indistinguishable from the Seville source group while a substantial number of the Santa Catalina de Guale samples are not closely related to any known source. Still, nearly two-thirds of the Santa Catalina samples are from a source that is probably related to this Seville source group. The nature of this relationship, which we suspect is depositionally influenced, will be investigated further in a later article.

\section{Discussion}

A major historical trend accompanying the development of production and distribution systems for Spanish export majolica was the European 
overseas expansion that began in the 15 th century. A continuing objective of the current majolica research is to gather new archaeological and compositional data to document the systems of majolica production and distribution that developed and changed as a result of the expansion of the Spanish empire. It is appropriate now to consider this broader question in the light of the new chemical data presented in this article.

These chemical data indicate that majolica supply systems for the two overseas colonial sites, one in North Africa and one in North America, were different. Qsar es-Seghir's Morisco wares were from a single source that is essentially indistinguishable from the Seville reference group. Santa Catalina de Guale's majolica came from multiple sources which, with the exception of one source, are clearly distinct from the Seville source. The existence of multiple majolica sources for Santa Catalina de Guale is potentially very significant. One hypothetical explanation for the later occurrence of multiple sources is that there was a change over time in the organization of Seville's majolica industry. Qsar es-Seghir (1458-1550) was established nearly 50 years before Columbus' first voyage, and Santa Catalina de Guale (1567-1680) was established over 100 years later, after an economic and administrative apparatus for Spain's New World holdings was already in place. The data from the two sites may therefore be a compositional approximation of Seville majolica production at two different stages in its development.

Perhaps the export majolica industry consisted at first of a small number of Triana shops that used a single source of clay. Then as a consequence of expanded demand in Seville and the New World the industry came to include many more shops, some of which may have been outside of Triana and perhaps even outside of Seville. This would explain the increased number of sources evident in the chemical data. The hypothesis is also consistent with documentary records that indicate a major expansion of Seville's ceramic industry (Lister and Lister 1987:160), an expansion that increased the need for raw materials to the point that legal disputes resulted over access to potting clay (Lister and Lister 1987:334, note 362).
It is worth noting here that Seville's inability to meet colonial demand was partly the cause for the late 16th-century advent of majolica production in New Spain (Deagan 1987:20). Further, Olin and Blackman's (1989) data show that a substantial number of these New World majolica products from Puebla also helped meet the demand for tableware at Santa Catalina de Guale.

Supply systems for the two sites must also be considered. Qsar es-Seghir was supported by the Portuguese Crown with direct subsidies used to acquire supplies in the nearby ports of Andalusia, including Seville (Boone 1980:45). In addition, the Portuguese had dealings with suppliers in the ports of Cádiz, Jerez del la Frontera, Malaga, and Puerto Santa Maria. Whatever the cause for the multiple sources at Santa Catalina de Guale may be, the existence of a single source at Qsar esSeghir provides significant information on the history of the majolica industries of Andalusia. The finding that the Qsar samples came only from Seville, the furthest of the possible supply ports, is evidence that there were no majolica industries at or near these other ports in the late 15 th and early 16 th centuries.

Logistics and administration determined that Spanish colonial supply systems for the circumCaribbean region would never be so straightforward as for the Portuguese in North Africa (Andrews 1978). In general, officials followed the principles of mercantilism rather than cost when dealing with the Spanish colonies. In 1503 the Crown established the Casa de Contratacion in Seville to regulate import and export trade with the New World (Andrews 1978:55), and by the mid16th century, trans-Atlantic shipping had been organized into two yearly convoys or flotas that supplied European goods to the colonies and transported precious metals from New Spain and Central and South America back to Spain (Haring 1947:304). Trade within the colonies was, in theory, also highly regulated. These strict commercial policies were responsible, at least in part, for the shortages of imported Spanish goods in the colonies attested to by both historical and archaeological data (Andrews 1978; Deagan 1983; South et al. 1988). Contraband trade, however, apparently 
augmented the legal trade in some cases, as numerous reports of Caribbean smuggling reached Spain in the 16th century (Andrews 1978:54). The question of contraband ceramics is now being investigated by Skowronek (1989) and must be considered more fully in future compositional research.

More specifically, the settlements of the colony of La Florida, including Santa Catalina de Guale, were supplied by a situado or yearly supply allowance which after 1574 came via St. Augustine from Mexico (Bushnell 1981:63-74; Sluiter 1985: Table 1). Shipments of European-made goods that came with the situado would have been assembled in Spain (most often in Seville) and sent from licensed ports there (McAlister 1984:245). While this arrangement did not rule out the official supply of non-Sevillian or even non-Spanish ceramics, it probably did exclude ceramics from European countries such as England and France that did not have friendly relations with the Spanish empire.

Thomas (1989) and Reitz (1989) on the other hand report evidence that the mission's Franciscan friars may have been engaged in unofficial com- mercial activity, which would have brought them into contact with suppliers of illicit European goods. French and English traders in the area cannot therefore be ruled out as suppliers of glazed tableware.

Still, the current compositional data are consistent with the interpretation that all of the Santa Catalina de Guale majolica, including the Mexican material from Puebla (Olin and Blackman 1989: 87-112), came from St. Augustine's situado. If this is true, then the multiple sources resulted from a changing organization of the Spanish industries supplying the colonies. The Santa Catalina samples, however, are also consistent with a combination of situado majolica and illicit majolica. Since St. Augustine and Santa Elena both relied on the situado, data from both sites will be useful for addressing this question, and it will also be necessary to determine the origin of the Old World majolica that does not match the Seville source. Until these additional data are available, both explanations for Santa Catalina de Guale's multiple sources remain as working hypotheses. 
.

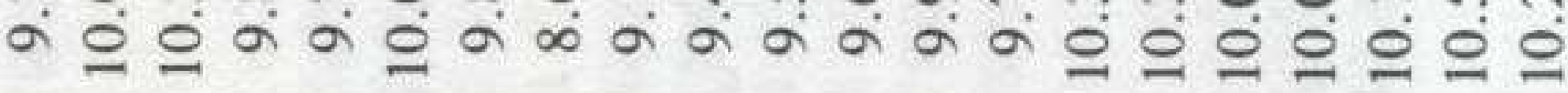

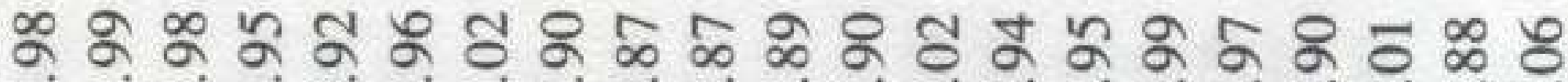
$000000-00000-00000-0$.

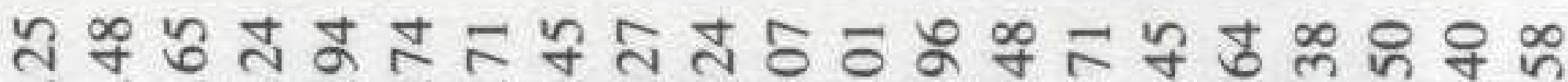

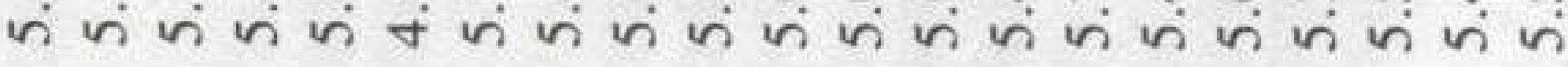

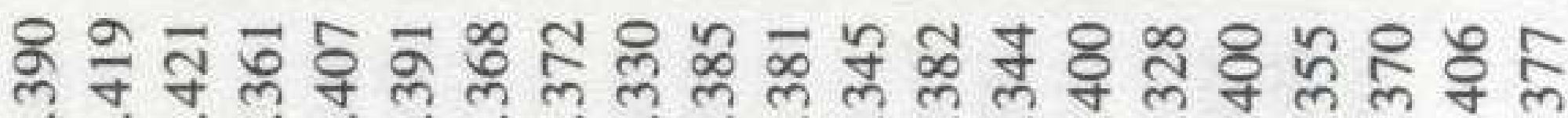
000000000000000000000

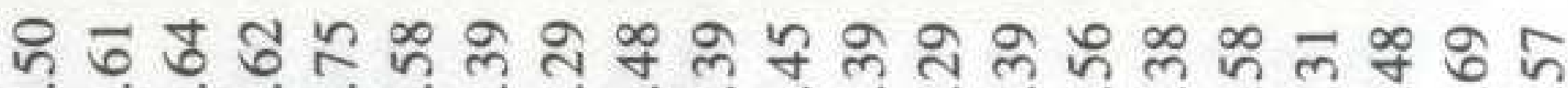

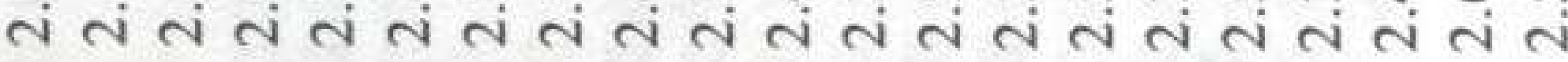

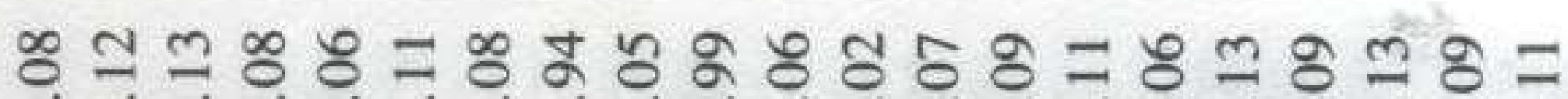

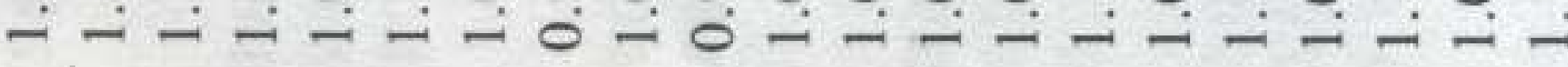
市六

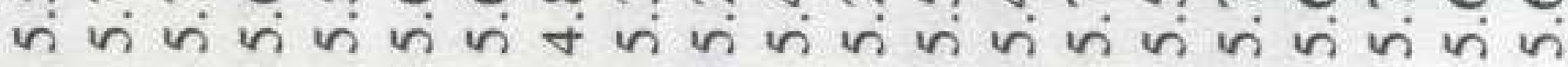

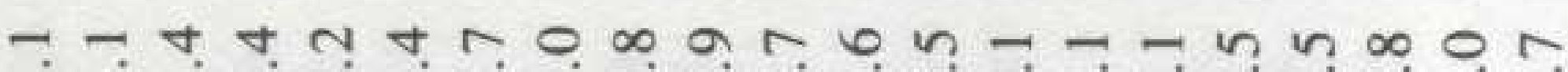

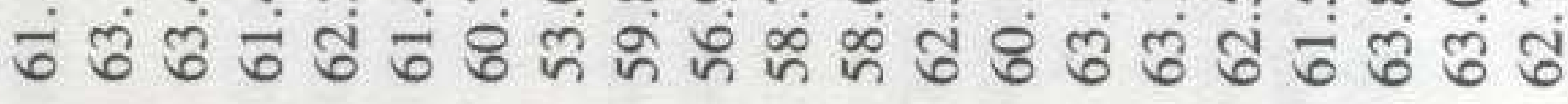
a $0000-+n+0+1-n-m 0 a \infty a m$ ஸि

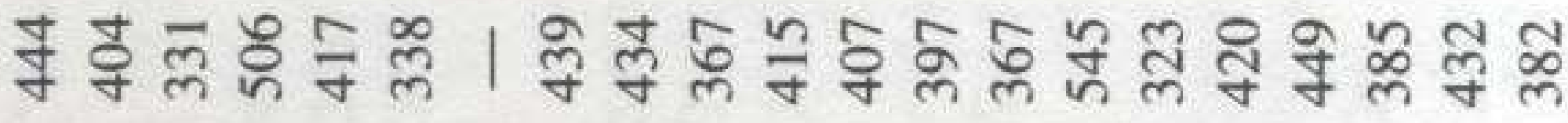
\& 유

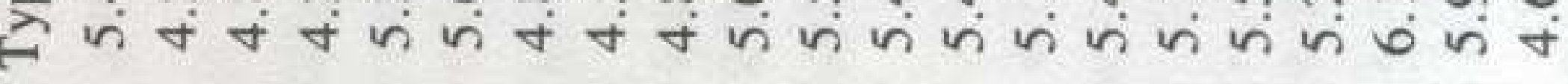

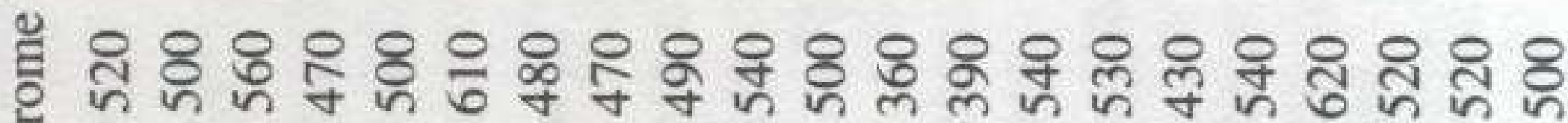

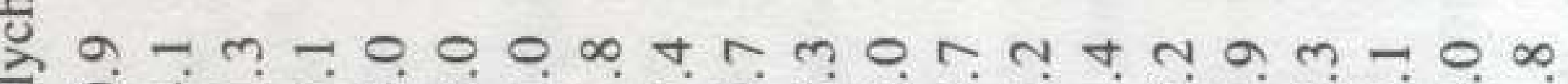
อ \&

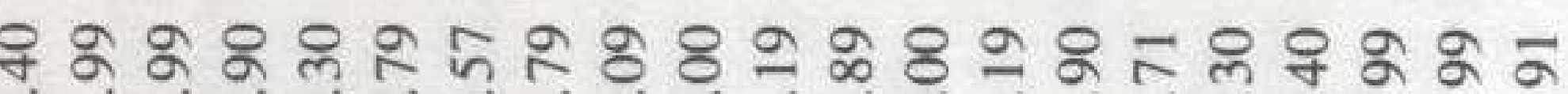

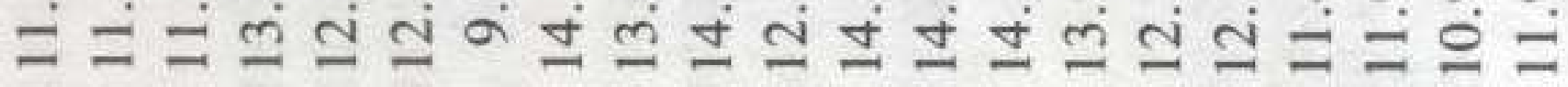

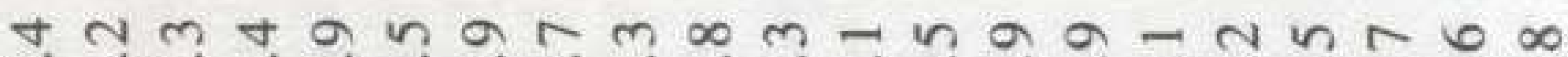

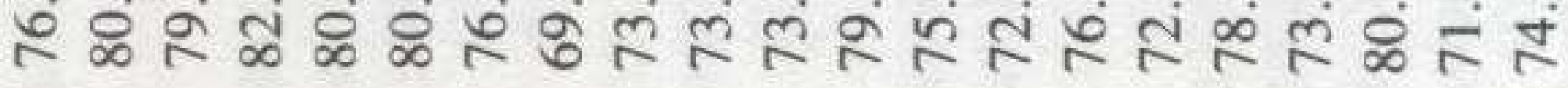

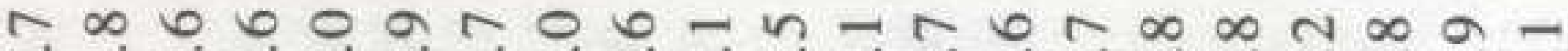

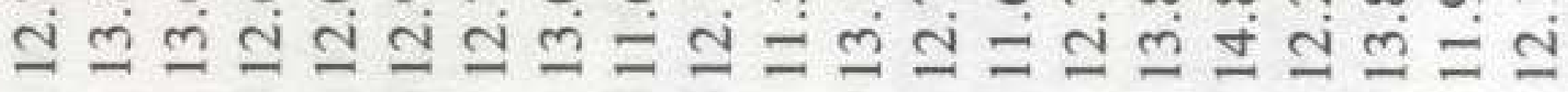
సี ํํ

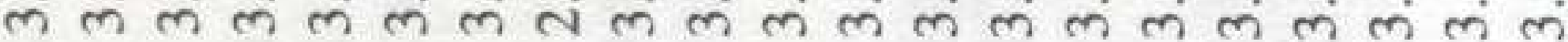
ก

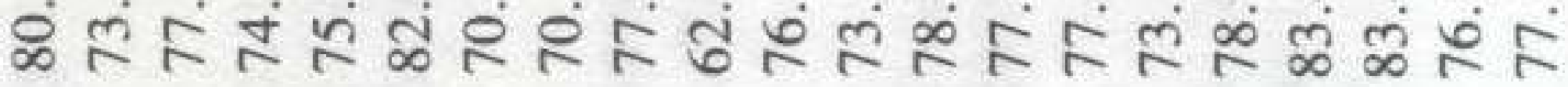

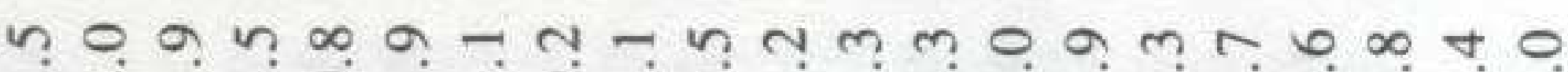

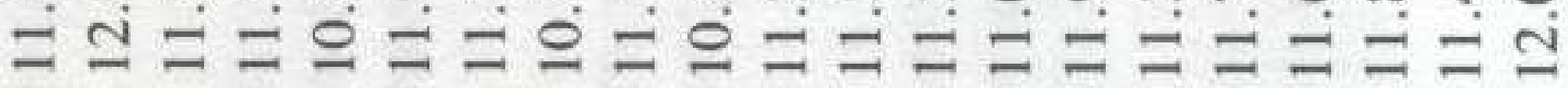

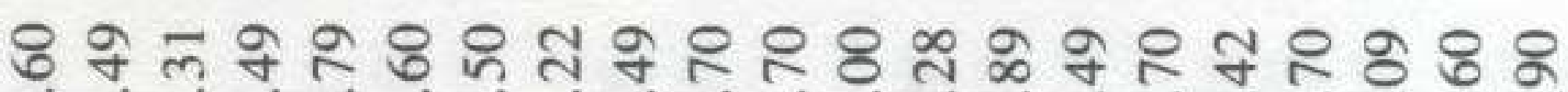

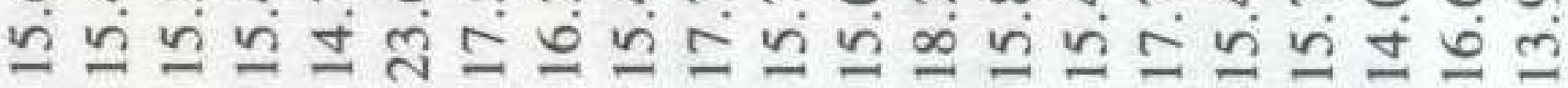
ल

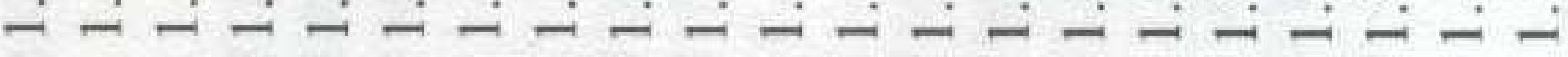

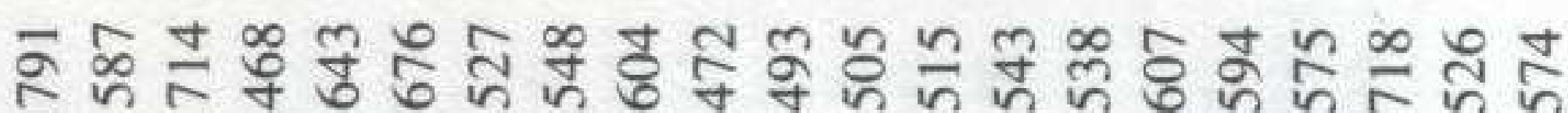
000000000000000000000

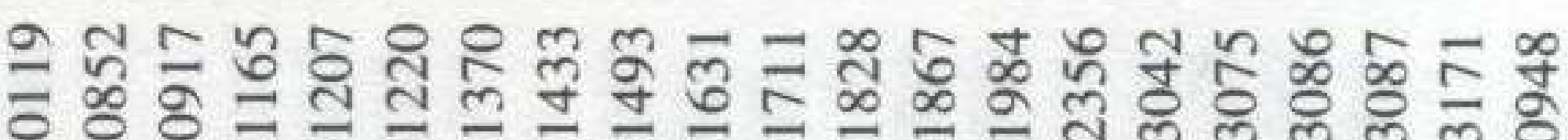

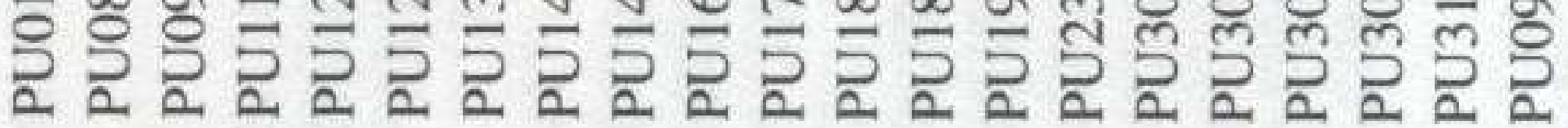

Oิ

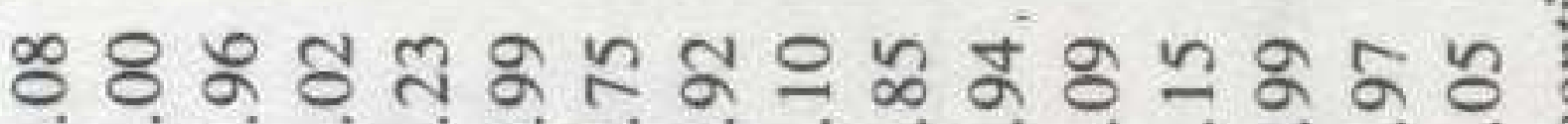
- $-01-000-00-100-0$ オே

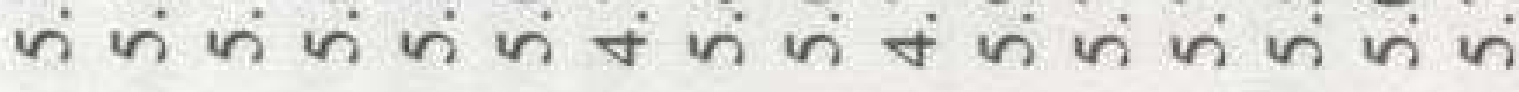

0000000000000000

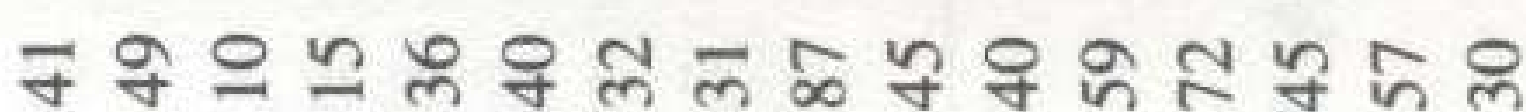

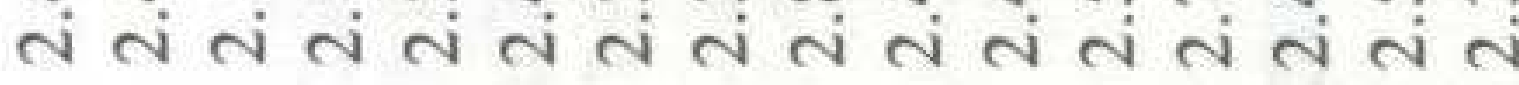

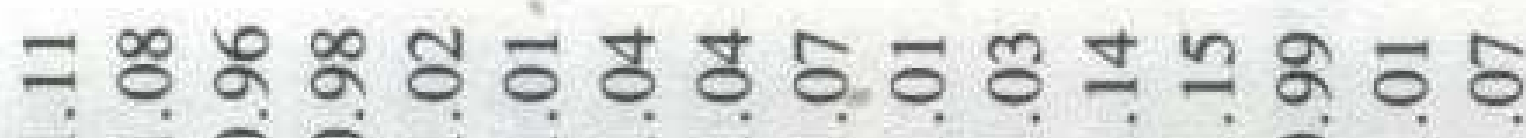
- - 00 - - - - - - - i 0 ดิทคต

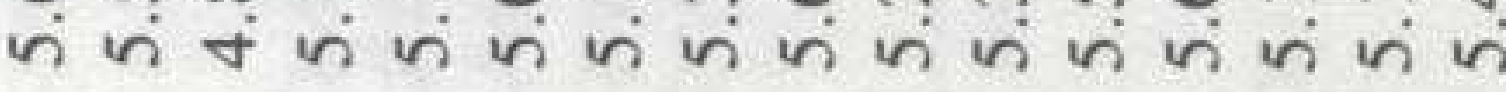
m ที่ กี กิ $\infty-n 0-t-a m m \infty \infty a n \infty$

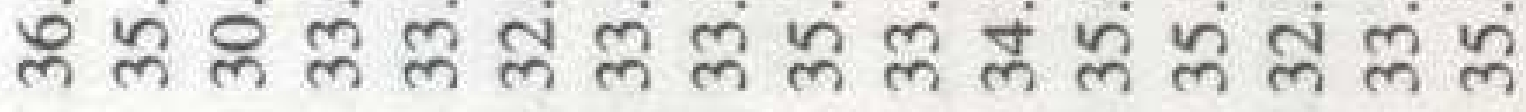

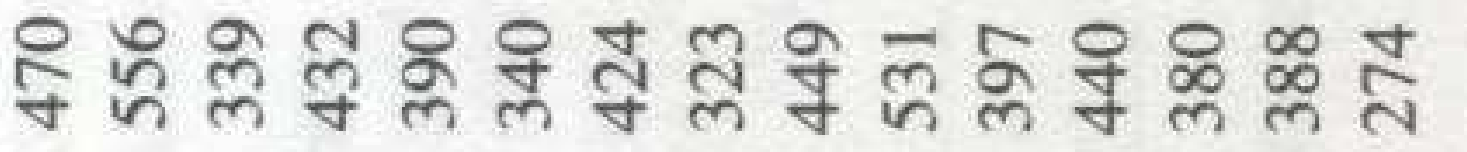

कิธ

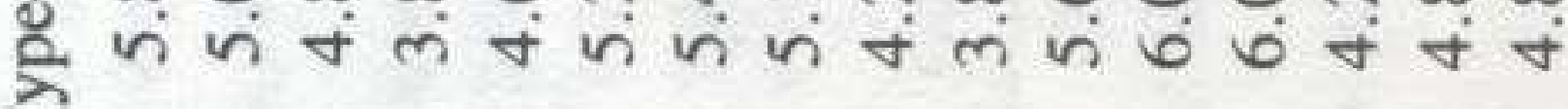
$\hat{F}$

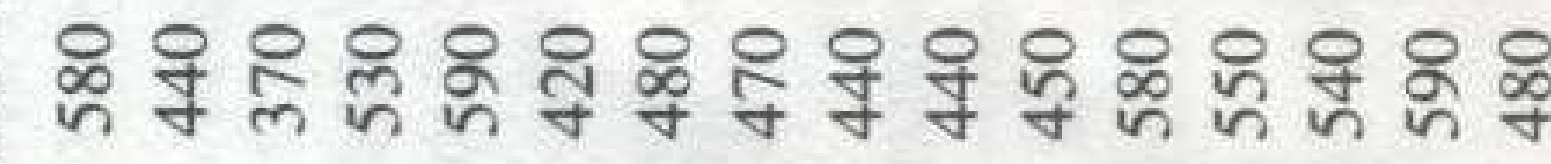

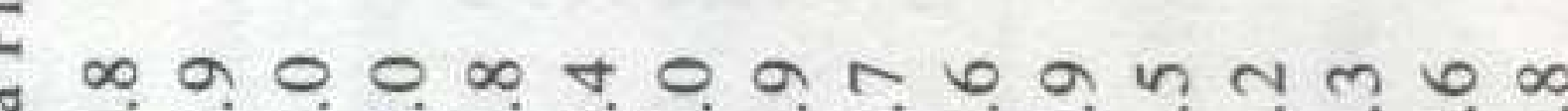
ป我 ㅇำ

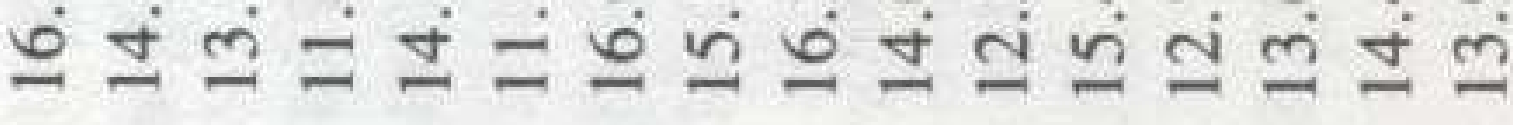
t $+0=\infty m \cap \infty 0$ \%

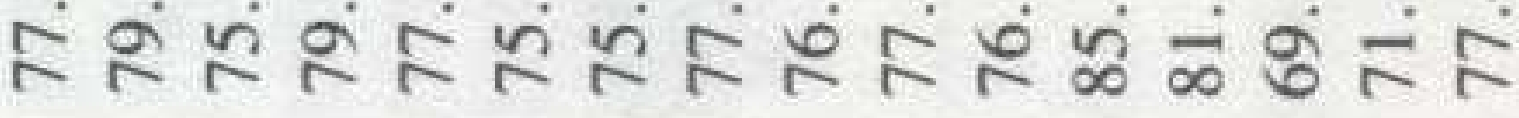
Nin $\mathrm{Nma}$ (

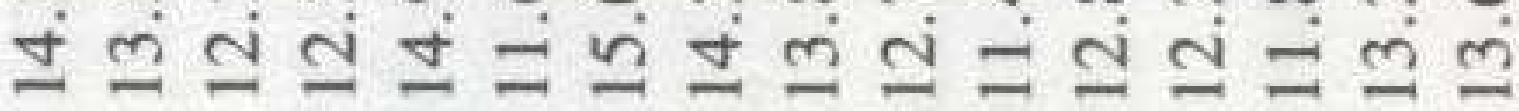
ธ

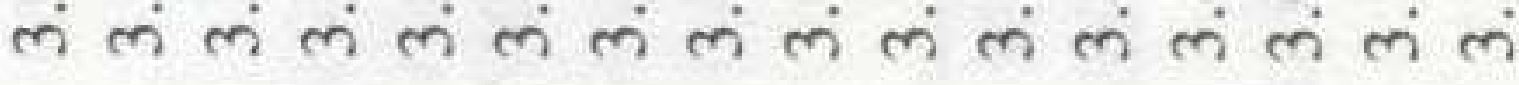

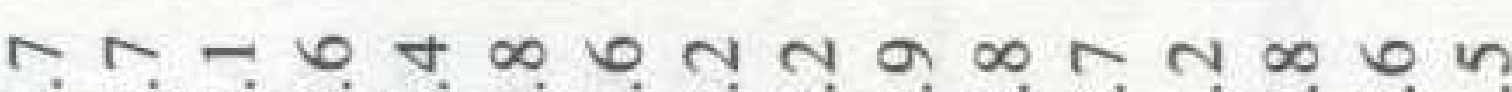

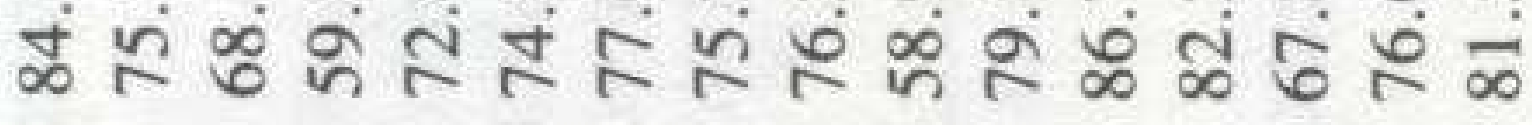

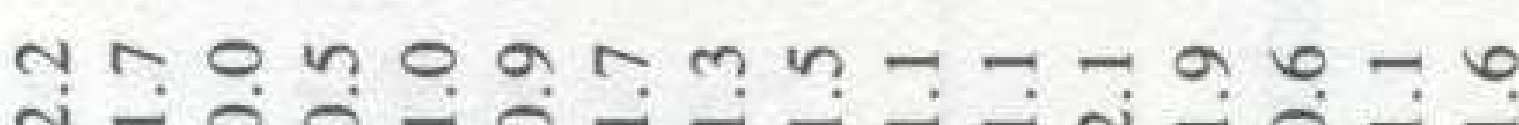

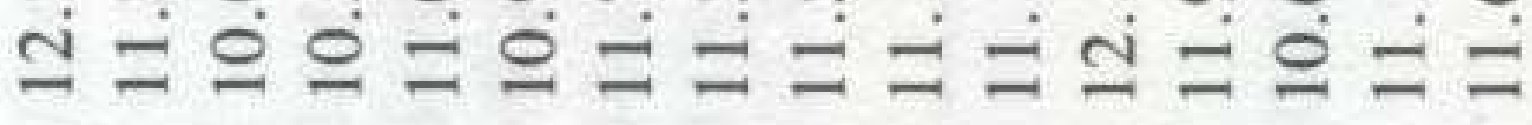

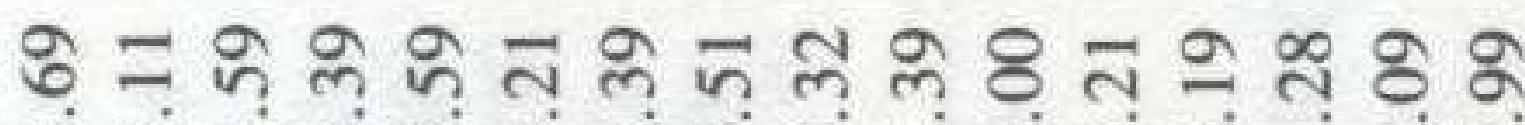

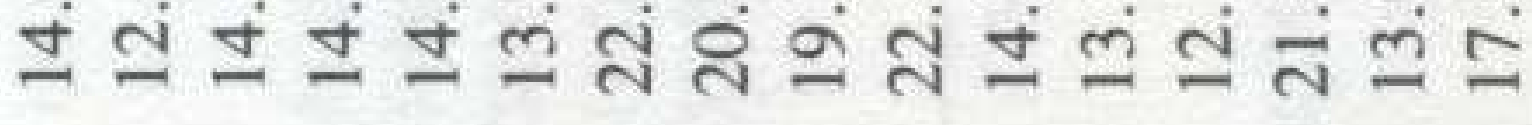

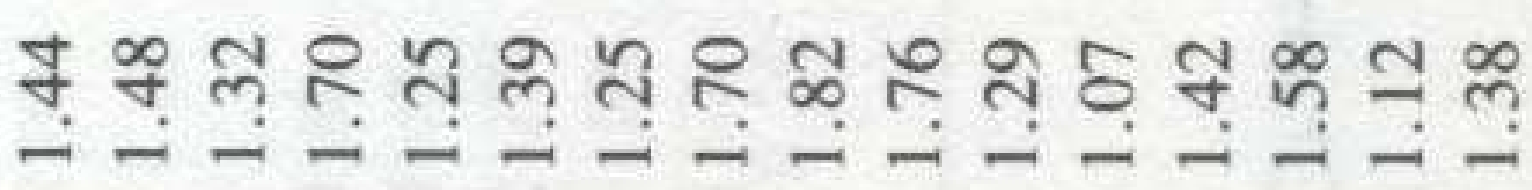

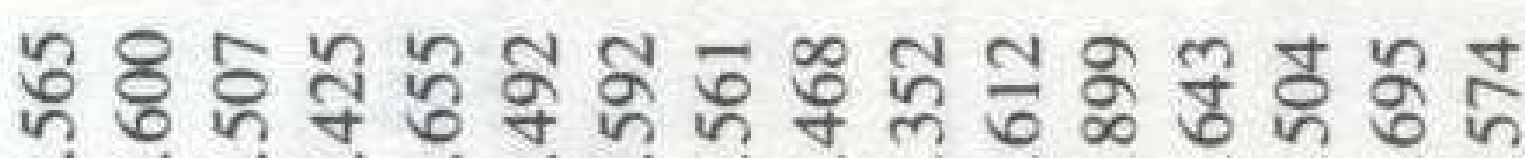
o 000000000000000

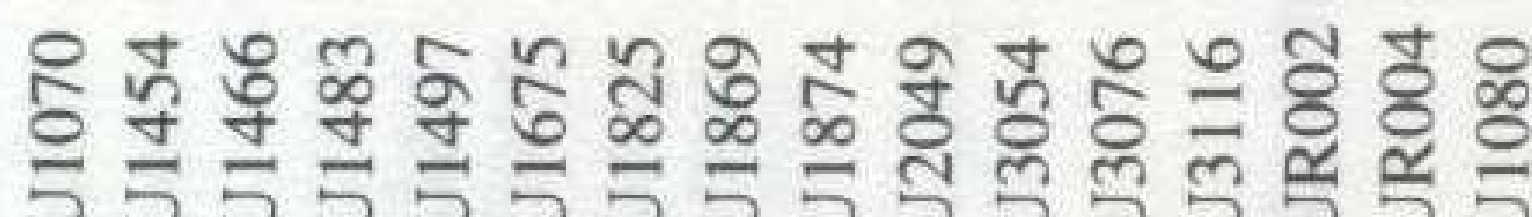

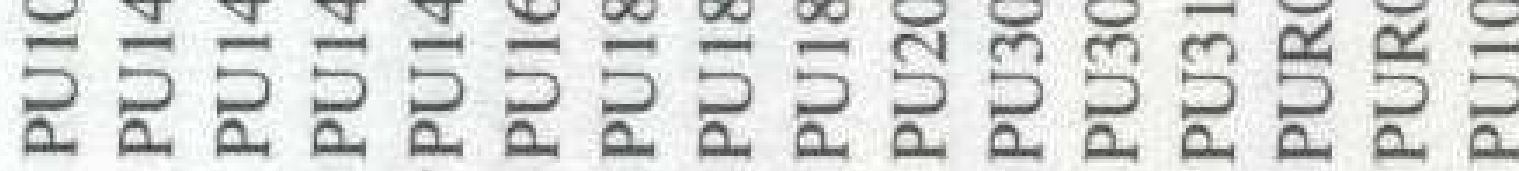




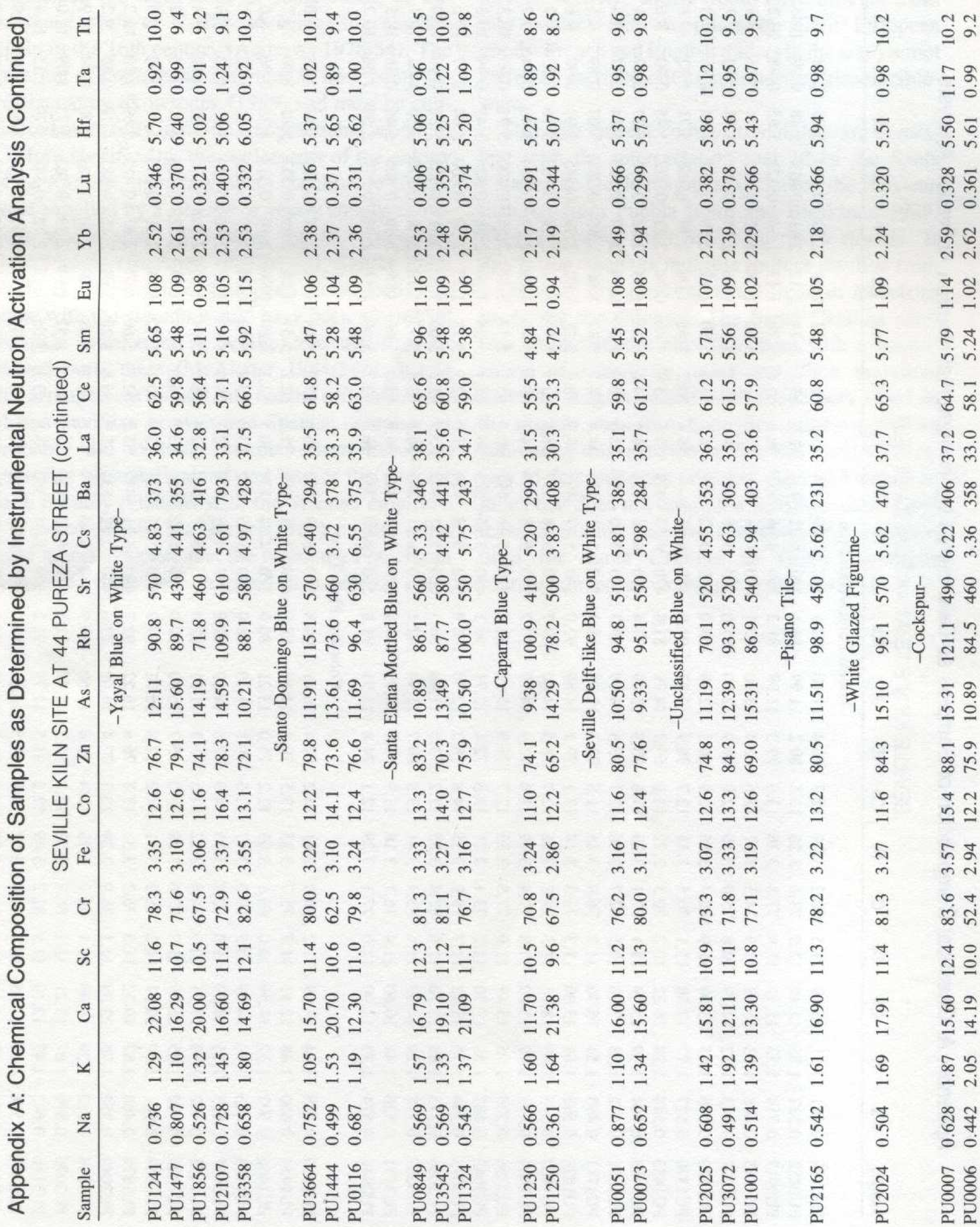




\begin{tabular}{|c|c|c|c|c|c|}
\hline $\bar{a} \dot{\infty}$ & $\because \tilde{0}$ & 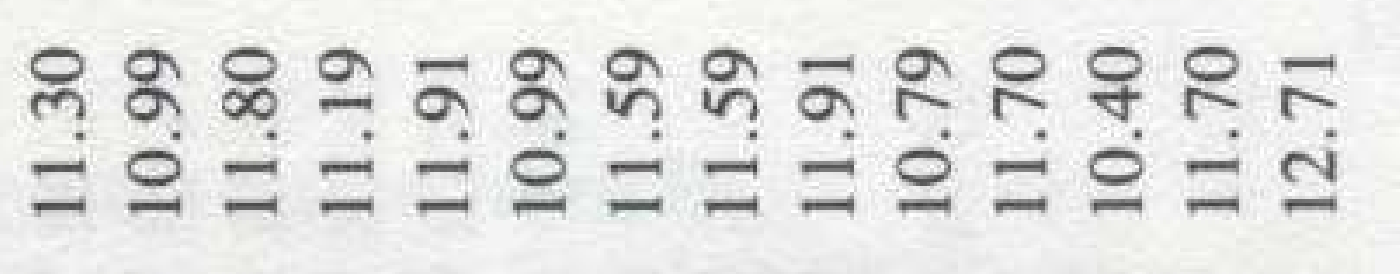 & 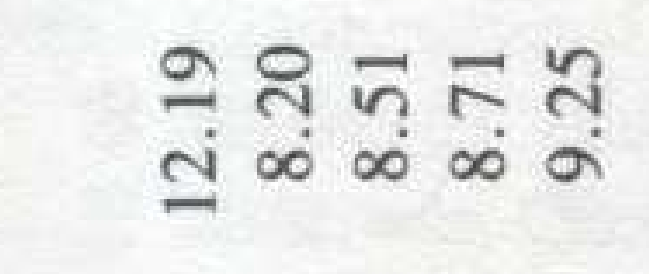 & $\begin{array}{l}2 \% \\
\stackrel{0}{0}\end{array}$ & \\
\hline కె & $\stackrel{+}{0} \stackrel{0}{0}$ & 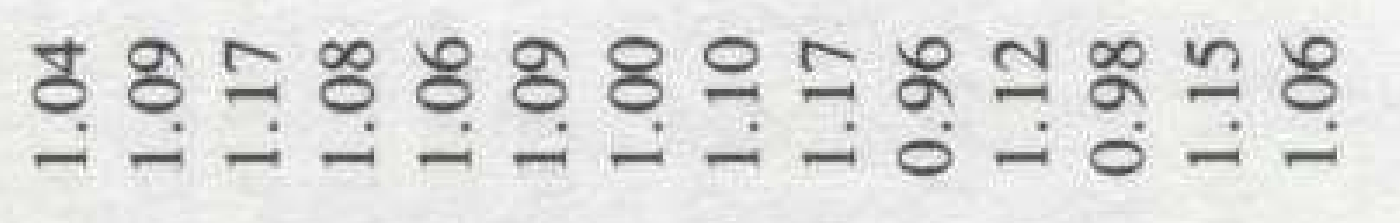 & 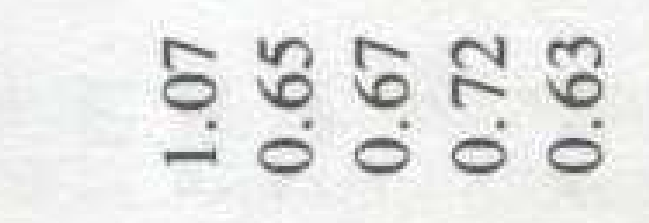 & gे \& & \\
\hline $\ln \frac{n}{n}$ & 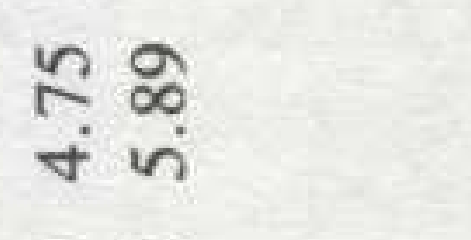 & そ) & 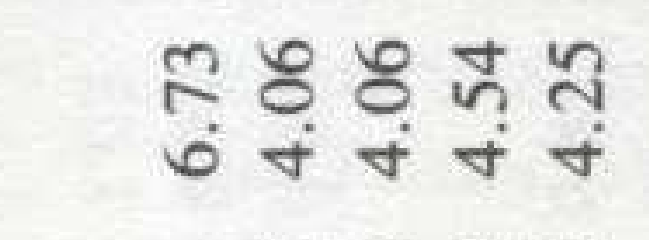 & io & \\
\hline ड़े⿺ & 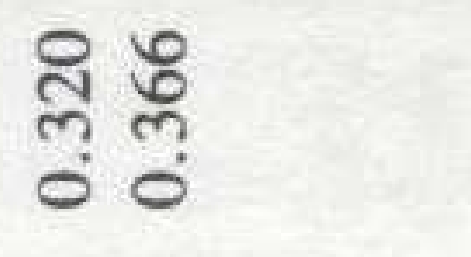 & 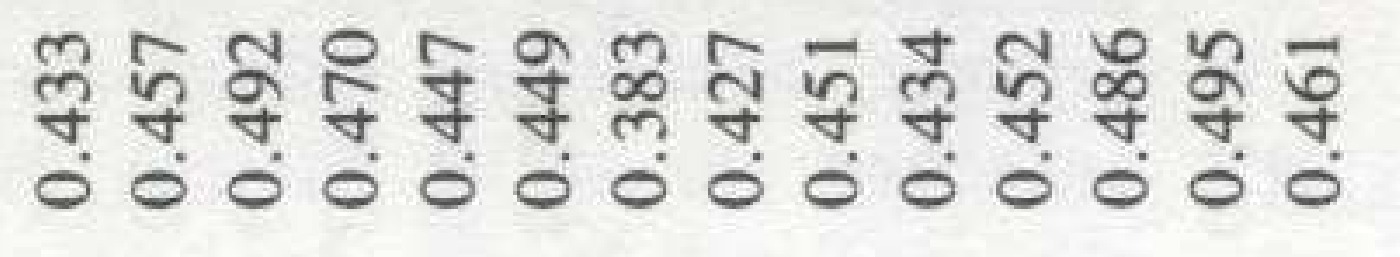 & 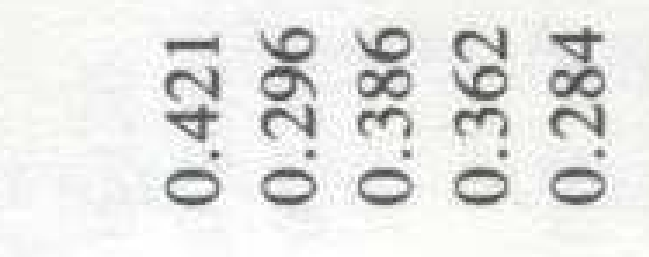 & ్ֻలి & \\
\hline שֶ. & 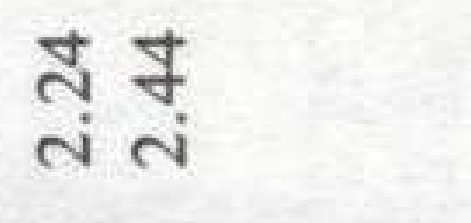 & 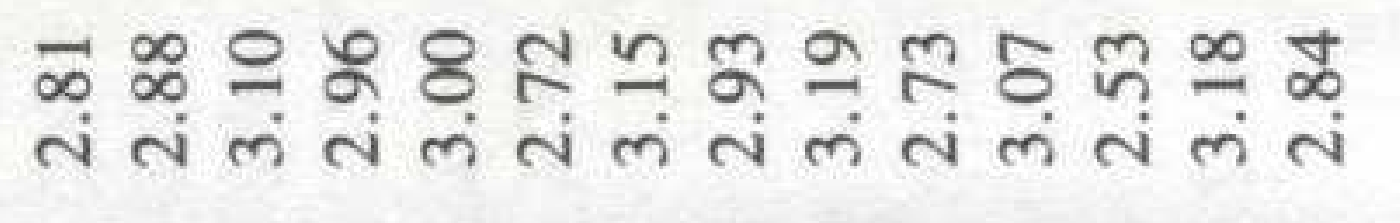 & 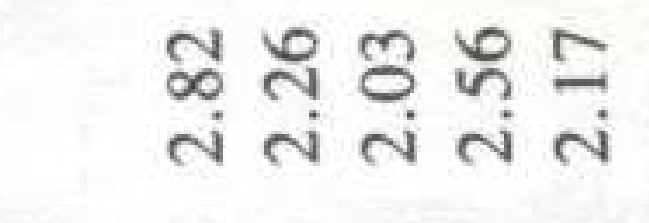 & 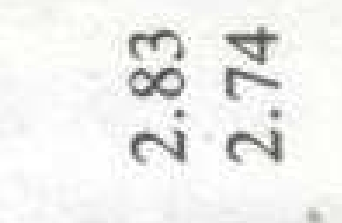 & \\
\hline is & 2 & సี สุ & 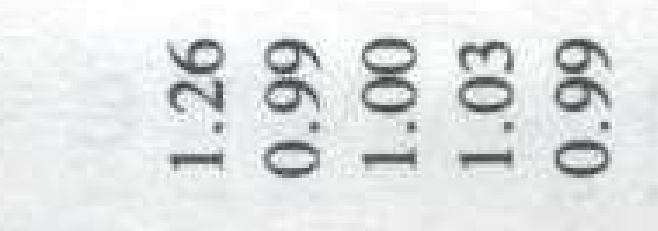 & $\cong$ & \\
\hline 象 & $\stackrel{+}{\stackrel{4}{7}}$ & 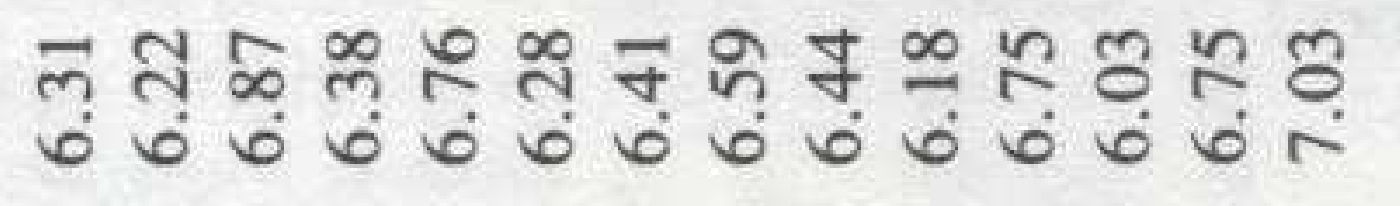 & 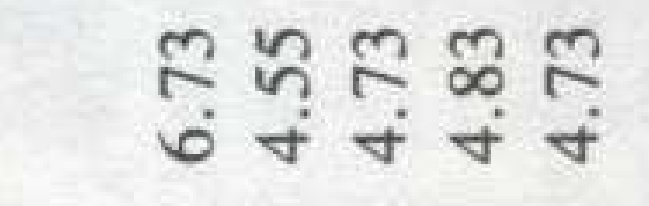 & 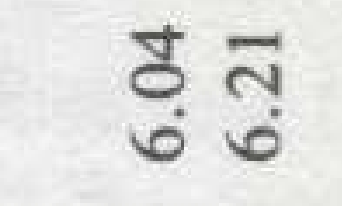 & \\
\hline $\begin{array}{ll}N \infty \\
\tilde{n}\end{array}$ & $\sum_{n}^{\infty} \stackrel{\infty}{i}$ & màn & 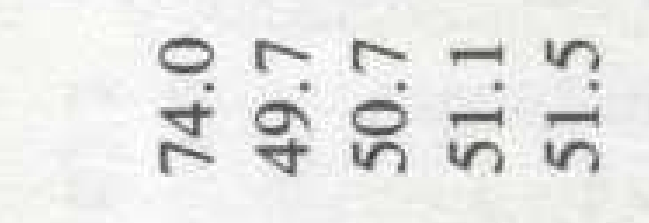 & iृ: & \\
\hline $\begin{array}{l}+0 \\
\text { mं ले }\end{array}$ & $\stackrel{m}{m} \stackrel{0}{\dot{m}}$ & 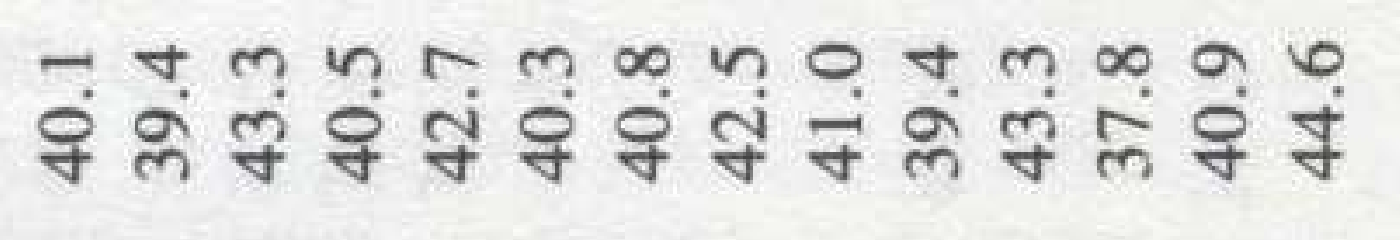 & 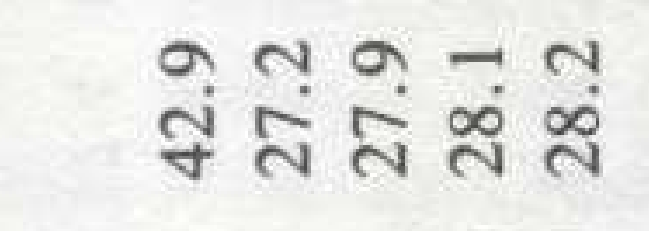 & $\begin{array}{l}\infty 0 \\
\infty \\
\infty\end{array}$ & \\
\hline 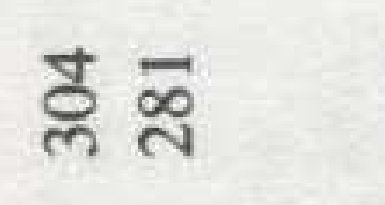 & ळे & 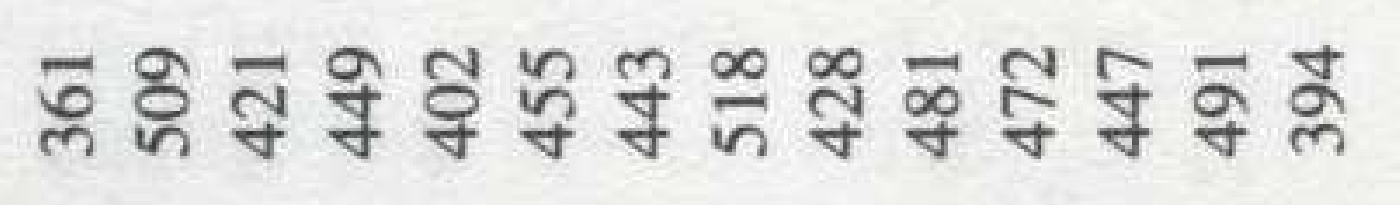 & 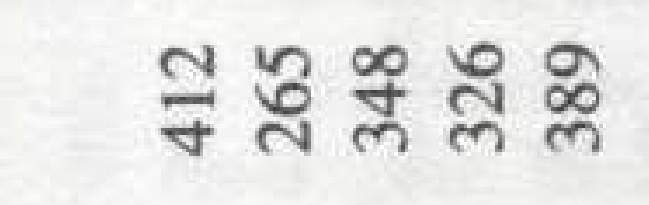 & 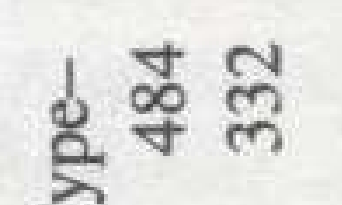 & $\sum_{i}^{\circ}$ \\
\hline 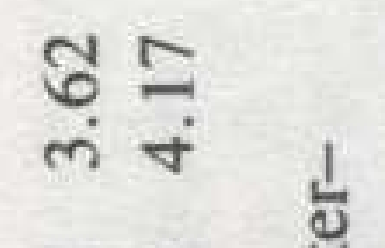 & \& & 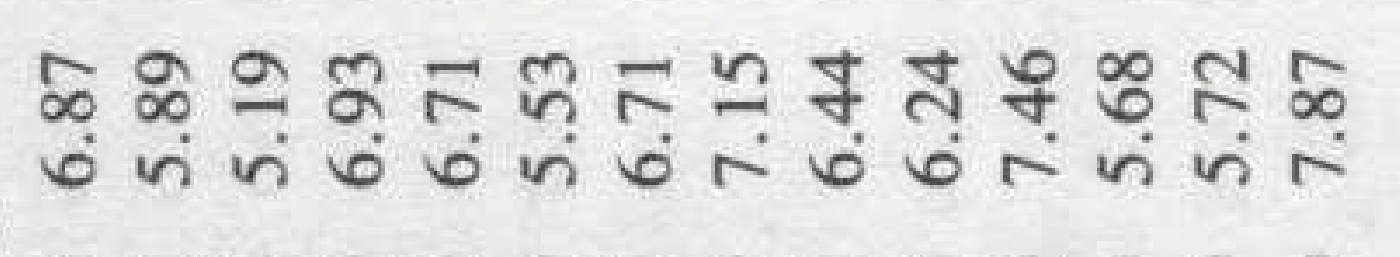 & 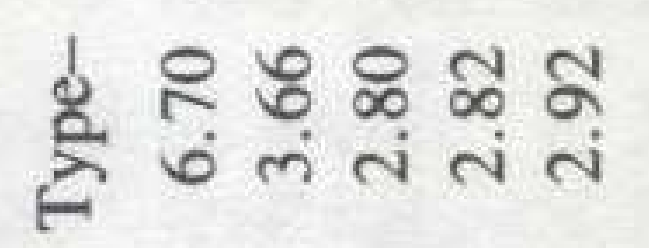 & 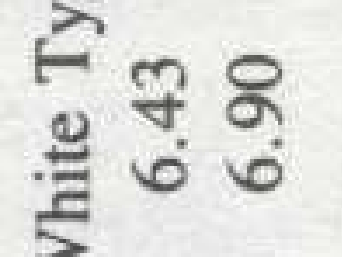 & $\frac{\mathrm{g}}{3}$ \\
\hline 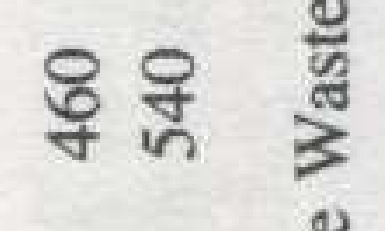 & 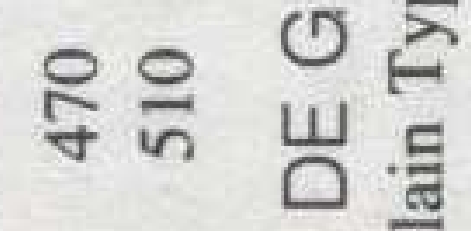 & 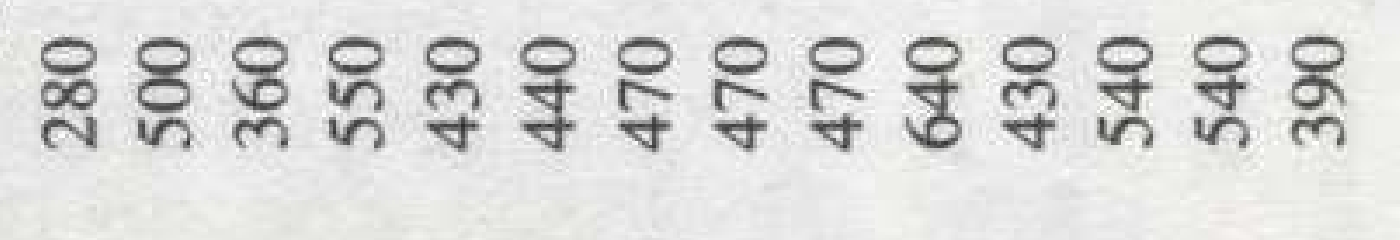 & 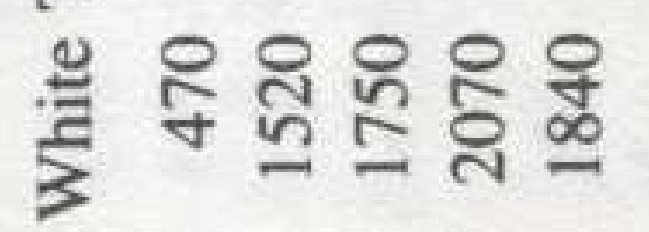 & 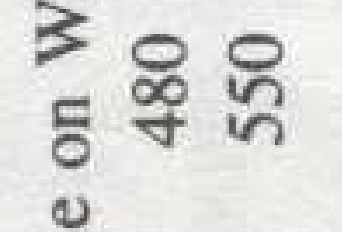 & 气 \\
\hline लूn & 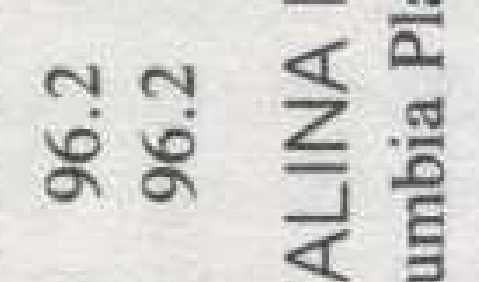 & 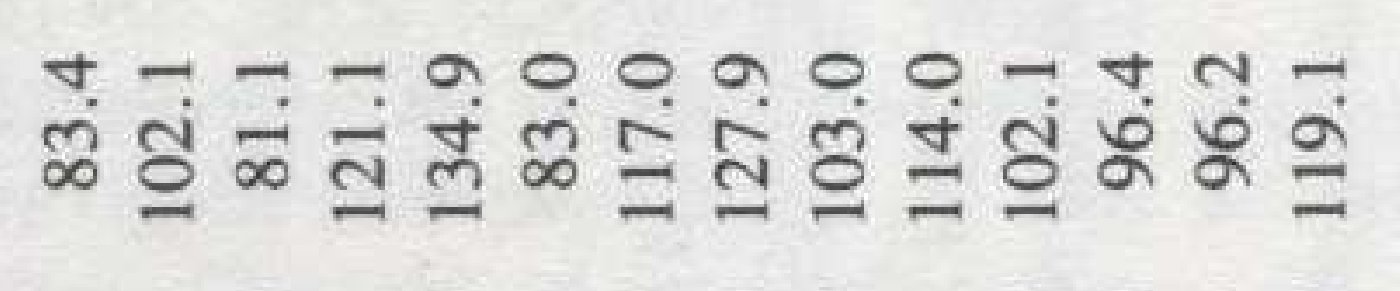 & 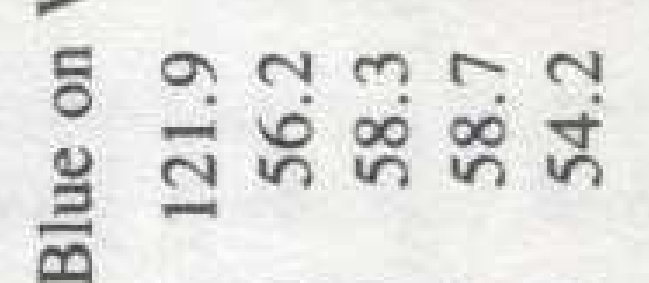 & 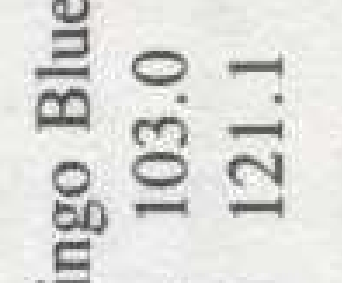 & 皇 \\
\hline 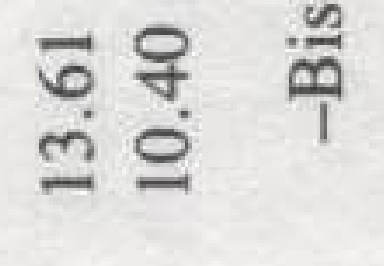 & 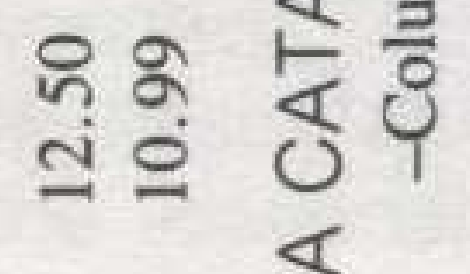 & 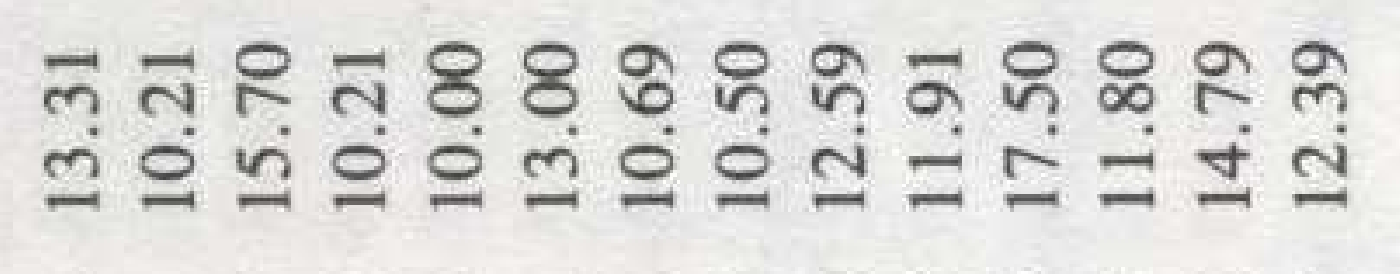 & 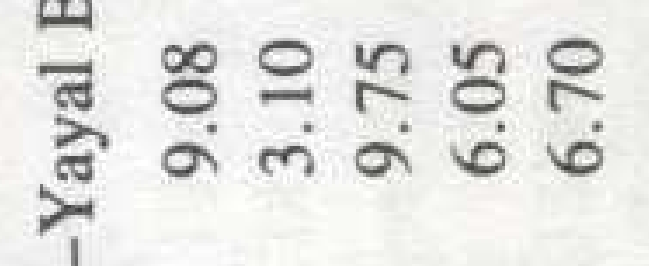 & 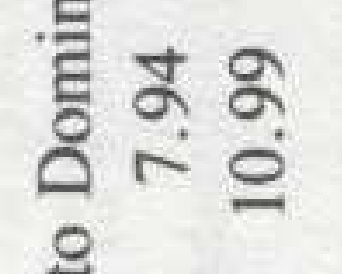 & $\sum_{\frac{\pi}{\pi}}^{\frac{\pi}{\pi}}$ \\
\hline$\stackrel{m}{\infty} \underset{\infty}{\infty}$ & サீ: & 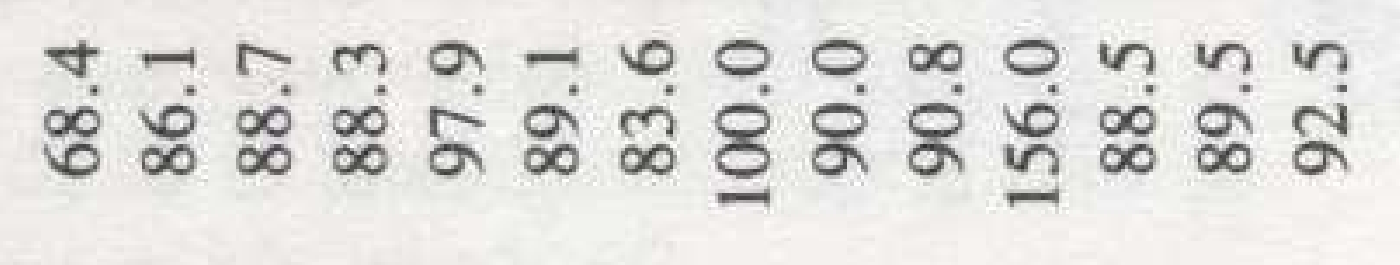 & 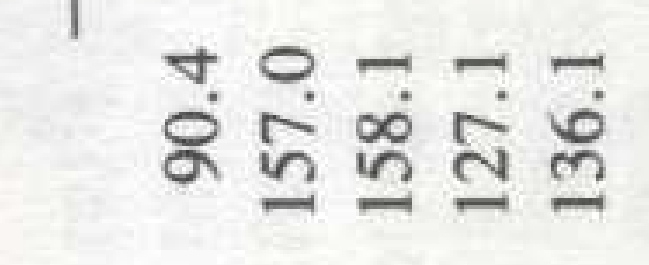 & 岕 市 & 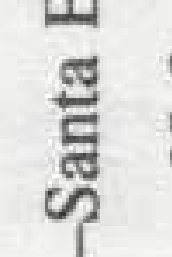 \\
\hline$\stackrel{\bullet}{\dot{I}}=$ & $\overrightarrow{\underline{\omega}} \stackrel{m}{=}$ & 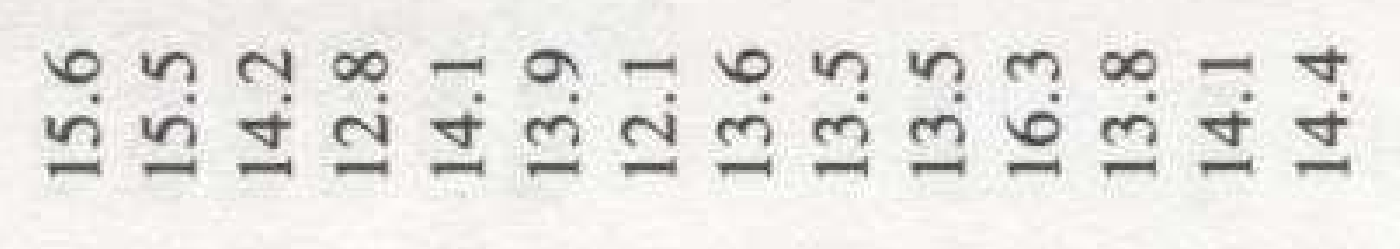 & 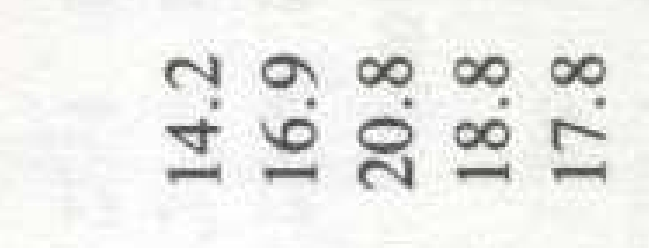 & $\ddot{m} \ddot{m}$ & \\
\hline$\frac{\pi}{4}$ & సू & 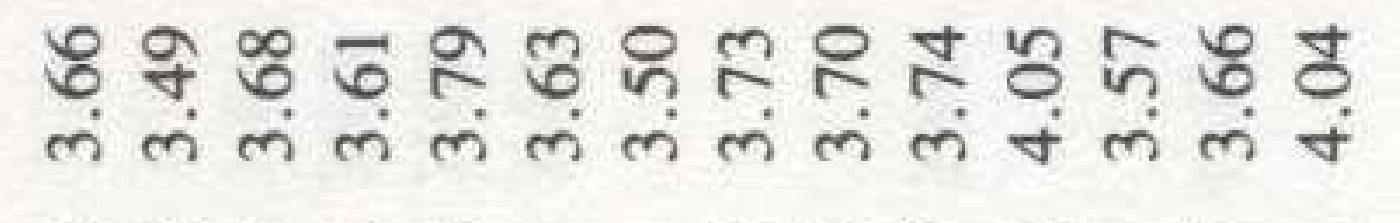 & 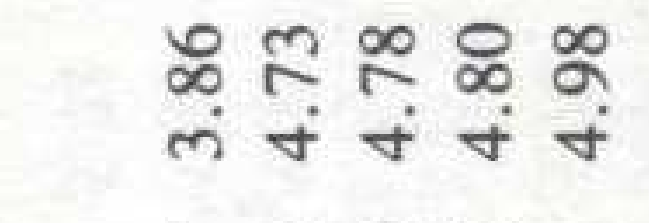 & 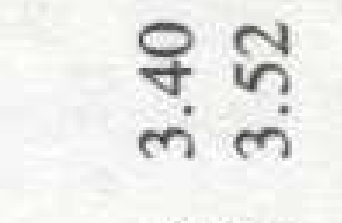 & \\
\hline ที่ & 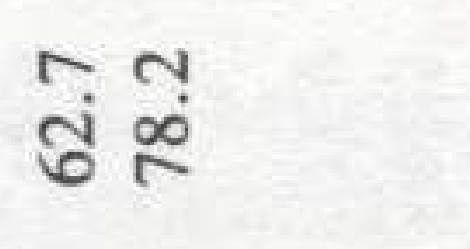 & 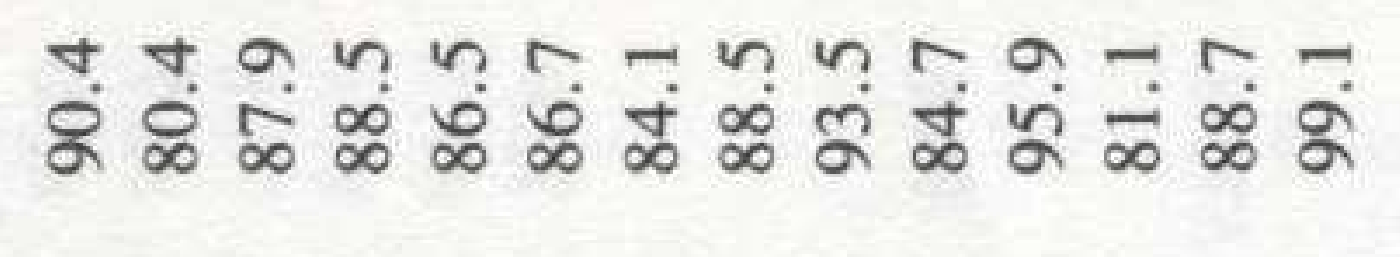 & 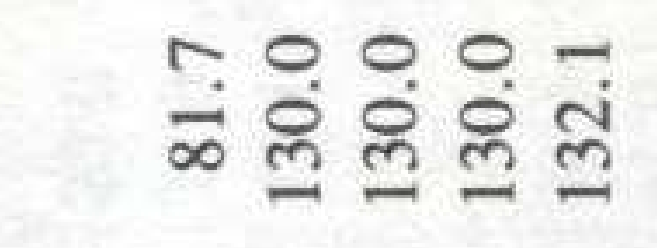 & $\underset{\leftarrow}{+}$ & \\
\hline @̊응 & 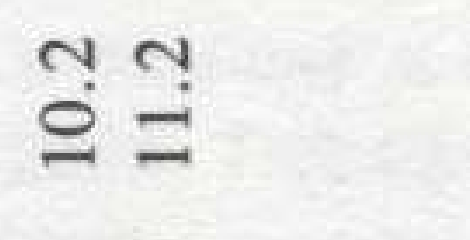 & 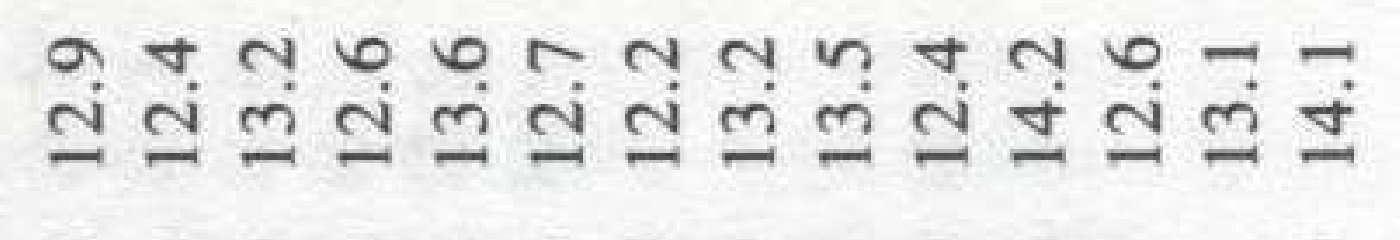 & ஸ் & $\stackrel{a}{=} \bar{I}$ & \\
\hline $\begin{array}{l}\stackrel{2}{\stackrel{9}{ \pm}} \\
\underline{ \pm}\end{array}$ & 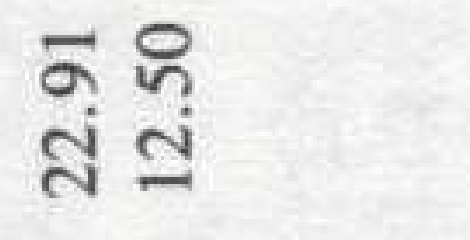 & 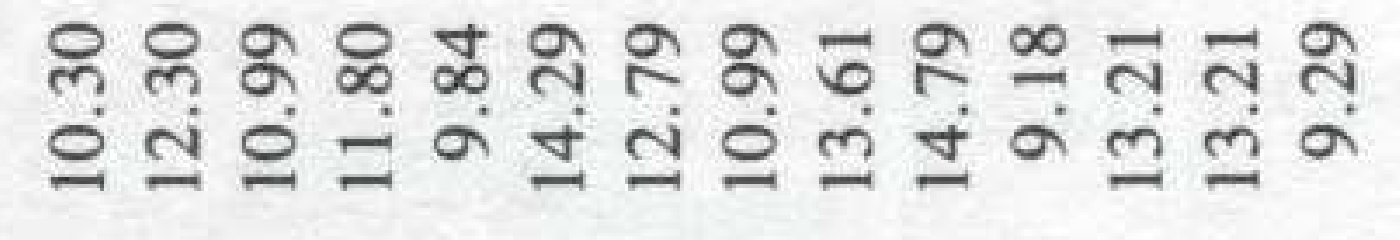 & 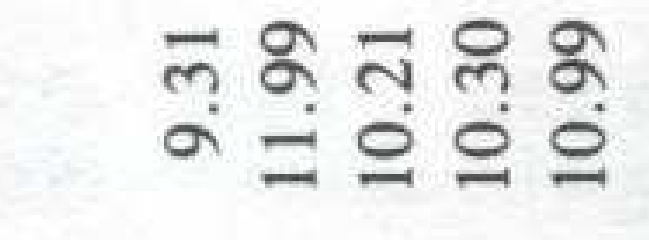 & $\bar{\sigma} \stackrel{?}{9}$ & \\
\hline$\approx 7$ & $\underline{6} \underline{n}$ & 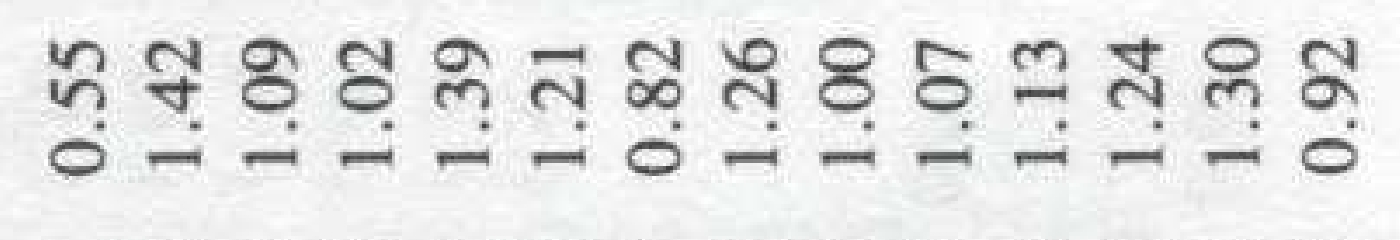 & 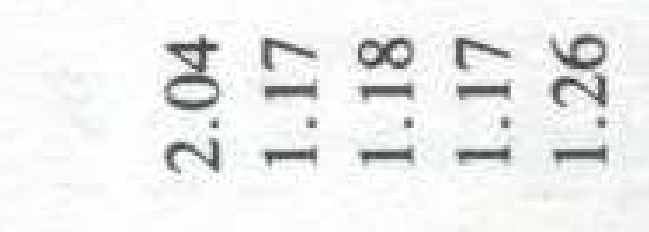 & $\overline{6}$ & \\
\hline 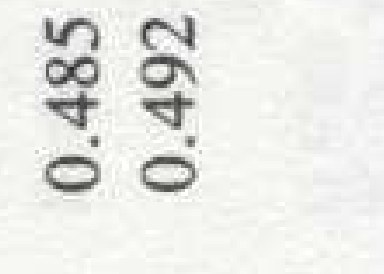 & $\begin{array}{l}\bar{\delta} \\
\vdots \\
0\end{array}$ & 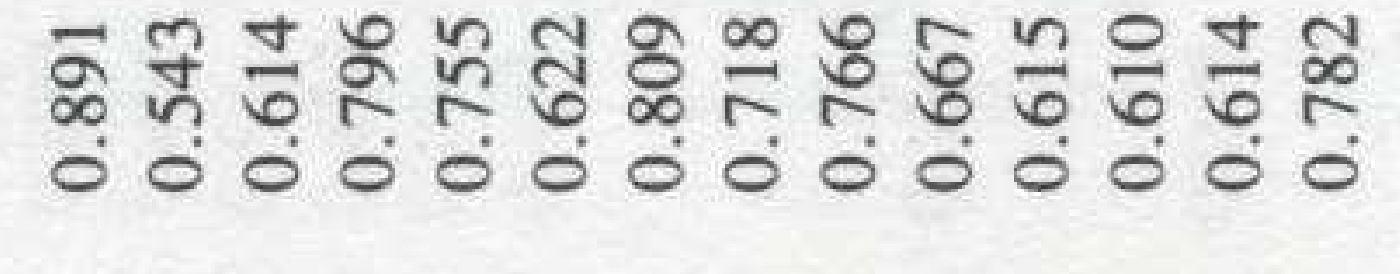 & 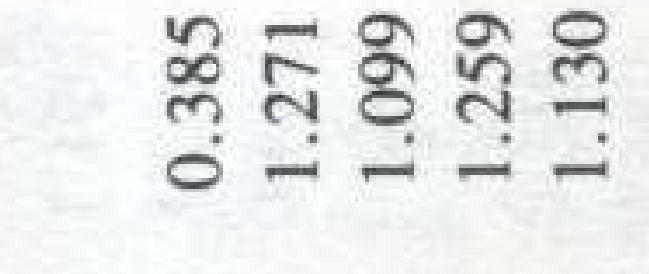 & $\begin{array}{l}\infty \\
\tilde{0} \\
0\end{array}$ & \\
\hline 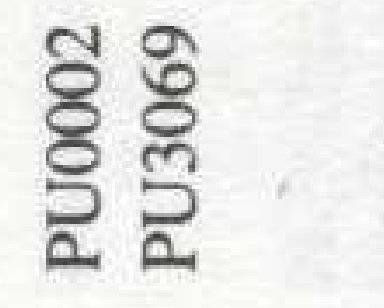 & 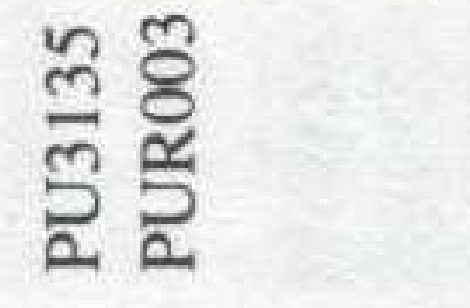 & 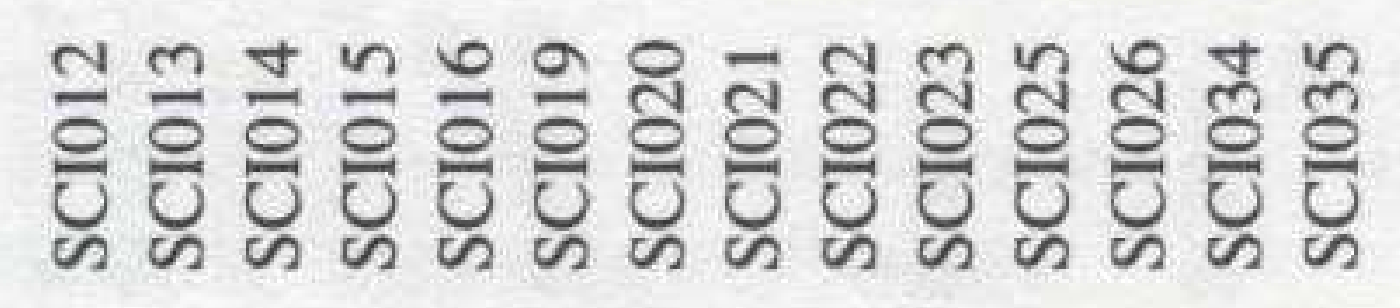 & 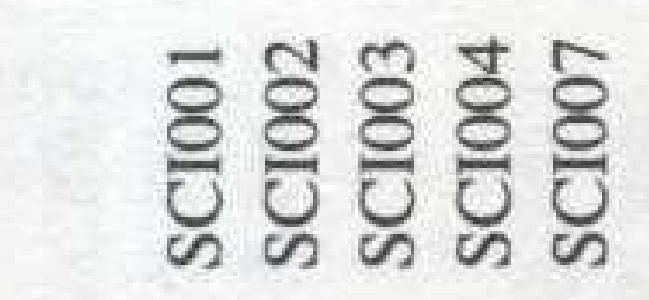 & छे & \\
\hline
\end{tabular}




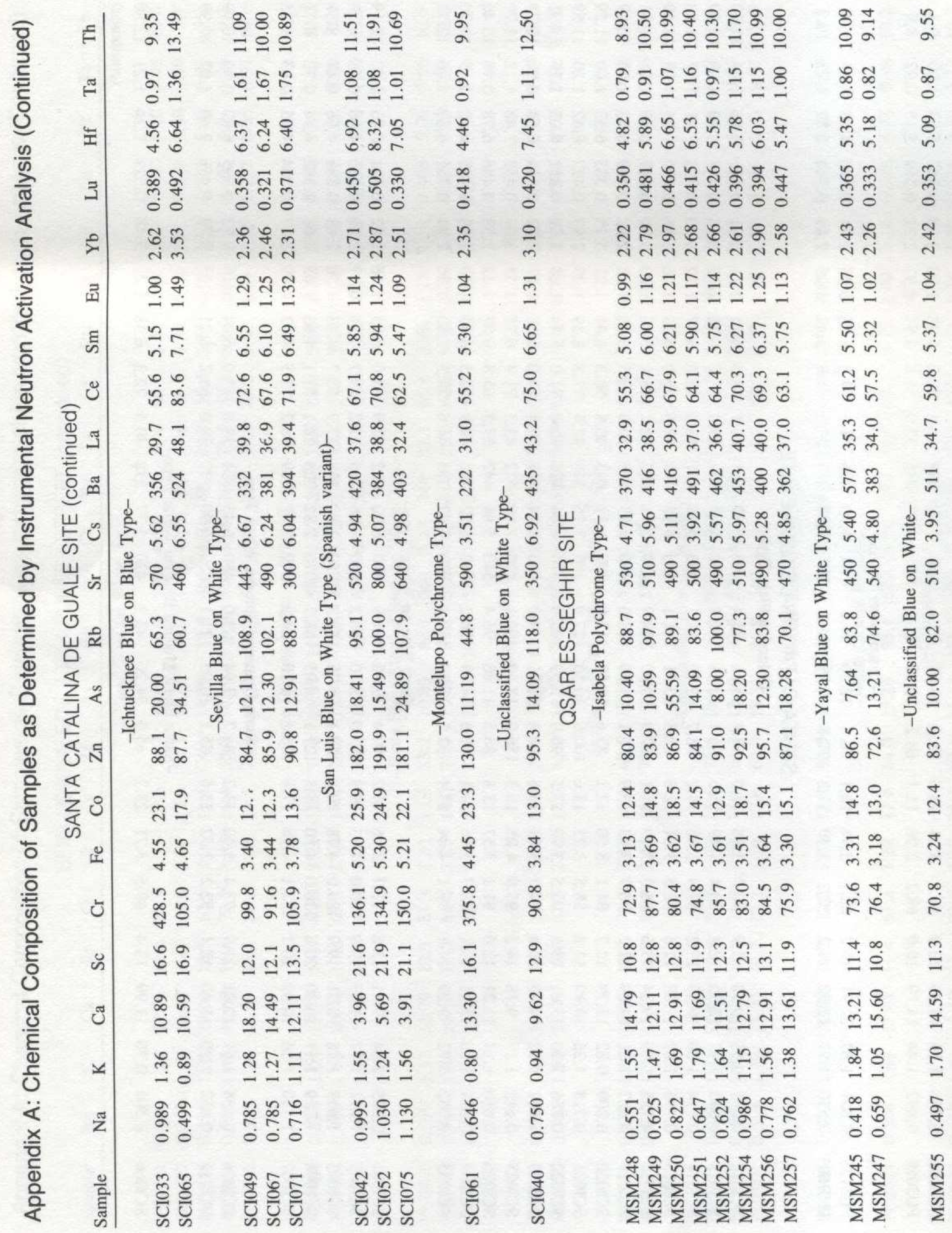




\section{ACKNOWLEDGMENTS}

Assistance in the research came from Richard Ahlborn, Charlotte Andersen, James Blackman, Kathleen Deagan, Michael Hughes, Anna Moore, Bonnie McEwan, Debra Peter, Mercedes Rueda, and David Hurst Thomas. Charles Redman and David Hurst Thomas allowed the sampling of ceramics from the sites of Qsar es-Seghir and Santa Catalina de Guale, respectively. Additional Seville samples were provided by Bonnie McEwan of the San Luis Archaeological and Historic Site. Data from Talavera and Manises and some of the Seville samples were selected and analyzed by Albert Jornet for a research project he conducted while a Postdoctoral Fellow in Materials Analysis at the Conservation Analytical Laboratory (Jornet et al. 1985a, 1985b). Funding and material support came from the U.S.-Spain Joint Committee for Cultural and Educational Cooperation and the Smithsonian Institution's Conservation Analytical Laboratory and Research Opportunities Fund. Indirect but substantial support also came from the University of Seville's Department of Archaeology and Prehistory and the Moroccan Archaeological Service. The data analysis employed programs available from the Smithsonian Institution's Archaeological Research Collection and Records (SARCAR), where the data are archived as well. The project received substantial assistance from the personnel of the Nuclear Methods Group, Division of Inorganic Analytical Chemistry and the Reactor Operation Division of the National Institute of Standards and Technology (formerly the National Bureau of Standards). The support of all of these institutions and individuals is gratefully acknowledged.

\section{REFERENCES}

AMores, F.E., Myers, J. OLIN,

ANd A. Pleguezuelo

1988 Determinación de la Mayolica Espanola de Exportación. Paper presented at the Forty-Sixth International Congress of Americanists, Amsterdam. Ms. \#21357 on file, Conservation Analytical Laboratory, Smithsonian Institution, Washington, D.C.

ANDREWS, KENNETH R.

1978 The Spanish Caribbean, Trade and Plunder, 15301630. Yale University Press, New Haven, Connecticut.

BERTI, G., AND L. TONGIORGI

1985 Ceramiche Importate della Spagna nell' Area Pisana dal XII al XV Secolo. Edizione Giglio, Florence.
BISHOP, R., AND H. NEFF

1989 Compositional Data Analysis. In Archaeological Chemistry 4, edited by Ralph O. Allen, pp. 57-86. American Chemical Society, Washington, D.C.

Bishop, R, R. RANDS, AND G. HOLLEY

1982 Ceramic Compositional Analysis in Archaeological Perspective. In Advances in Archaeological Method and Theory, Vol. 5, edited by Michael Schiffer, pp. 275-330. Academic Press, New York.

Blackman, M. James, Sophie Mery, and Rita P. WRIGHT

1989 Production and Exchange of Ceramics on the Oman Peninsula from the Perspective of Hili. Journal of Field Archaeology 16:61-77.

BOONE, JAMES L. III

1980 Artifact Deposition and Demographic Change: An Archaeological Case Study of Medieval Colonialism. Unpublished $\mathrm{Ph} . \mathrm{D}$. dissertation, Department of Anthropology, State University of New York, Binghamton, New York.

1984 Majolica Escudillas of the 15th and 16th Centuries: A Typological Analysis of 55 Examples from Qsar es-Seghir. Historical Archaeology 18(1):76-86.

BUSHNELL, AMY

1981 The King's Coffer (Proprietors of the Spanish Florida Treasury, 1565-1702). University Presses of Florida, Gainesville.

\section{Caiger-Smith, Alan}

1973 Tin-Glaze Pottery in Europe and the Islamic World, the Tradition of 1,000 Years in Maiolica, Faience, and Delft. Faber and Faber, London.

\section{DEAGan, KathleEN}

1983 Spanish St. Augustine: The Archaeology of a Colonial Creole Community. Academic Press, New York.

1987 Artifacts of the Spanish Colonies of Florida and the Caribbean, 1500-1800. Vol. 1, Ceramics, Glass, and Beads. Smithsonian Institution Press, Washington, D.C.

GoGGIN, JoHN M.

1968 Spanish Majolica in the New World. Yale University Publications in Anthropology No. 72. Yale University, New Haven, Connecticut.

Gonzalez, F., and G. Garcia

1966 Arcillas cerámicas de Andalucia III: Guadalquivir y Corbones en la Provincia de Sevilla. Boletín de la Sociedad Española de Cerámica 5(2):229-245.

Hamer, Frank

1975 A Dictionary of Potter's Techniques. Watson-Guptill, New York.

HARING, C.H.

1947 The Spanish Empire in America. Harcourt Brace Jovanovich, New York. 


\section{HaRbotTle, GarmaN}

1976 Activation Analysis in Archaeology. Radiochemistry 3:33-72.

1982 Chemical Characterization in Archaeology. In Contexts for Prehistoric Exchange, edited by Timothy Earle and Jonathon Ericson, pp. 13-51. Academic Press, New York.

HuRST, J.G.

1977 Spanish Pottery Imported into Medieval Britain. Medieval Archaeology 21:68-105.

1986 Late Medieval Iberian Pottery Imported into the Low Countries. In Segundo Colloquio Internacional de Ceramica Medieval en el Mediterraneo Occidental, edited by Juan Zozaya, pp. 347-351. Ministerio de Cultura, Madrid.

Jornet, Albert, M. James Blackman, AND

JACQUELINE S. OLIN

1985a XIII-XVIII Century Ceramics from the Paterna-Manises Area (Spain). In Ceramics and Civilization, edited by David Kingery, pp. 235-255. American Ceramic Society, Columbus, Ohio.

1985b Investigation of Post-Medieval Glazed Ware from the Sevilla and Talavera-Puente Areas. Paper presented at the 87th Annual Meeting of the American Ceramic Society, Cincinnati, Ohio.

Lister, Florence, AND RoBert Lister

1974 Maiolica in Spanish Colonial America. Historical Archaeology 8:17-52.

1982 Sixteenth Century Maiolica Pottery in the Valley of Mexico. Anthropological Papers of the University of Arizona No. 3. University of Arizona Press, Tucson.

1987 Andalusian Ceramics in Spain and New Spain, a Cultural Register from the Third Century B.C. to 1700. University of Arizona Press, Tucson.

LoRenzo, Jose, AND MANuel Vera

1987 Informe-Memoria de Las Actividades Arqueológicas Realizadas en Calle Pureza 44 y Pelay Correa 1517-19. Anuario Arqueologico de Andalucia, pp. 574-580. Consejeria de Cultura de la Junta de Andalucia, Seville.

Maggetti, Marino, Harold Westley, and

JACQUELINE S. OLIN

1984 Provenance and Technical Studies of Mexican Majolica Using Elemental and Phase Analysis. In Archaeological Chemistry 3, edited by J. Lambert, pp. 151-191. American Chemical Society, Washington, D.C.

MCAlister, LyLE N.

1984 Europe and the World in the Age of Expansion. Vol. 3, Spain and Portugal in the New World, 14921700. University of Minnesota Press, Minneapolis.

McEwan, BonNiE G.

1988 An Archaeological Perspective of Sixteenth Century
Spanish Life in the Old World and the Americas. Unpublished $\mathrm{Ph} . \mathrm{D}$. dissertation, Department of Anthropology, University of Florida, Gainesville.

Morales, Alfredo J.

1977 Francisco Niculoso Pisano. Excma. Diputación Provincial de Sevilla, Barcelona, Spain.

Olin, Jacqueline S., and M. James Blackman

1989 Compositional Classification of Spanish Colonial Majolica. In Archaeological Chemistry 4, edited by Ralph O. Allen, pp. 87-112. American Chemical Society, Washington, D.C.

Olin, JacQueline S., Garman Harbottle, and

EDWARD V. SAYRE

1978 Elemental Compositions of Spanish and Spanish Colonial Majolica in the Identification of Provenience. In Archaeological Chemistry 2, edited by Giles F. Carter, pp. 200-229. American Chemical Society, Washington, D.C.

PERLman, IsADORE, AND Frank ASARo

1969 Pottery Analysis by Neutron Activation. Archaeometry 11:21-52.

Pleguezuelo, Alfonso

1985 La Ceramica de Triana (s. XVI-XIX). Colección Artistas Plasticos No. 8. Caja General de Ahorros, Granada, Spain.

1989 Una Approximación desde la Arqueología Historica a la Obra de Francisco Niculoso. Ms. \#21356 on file, Conservation Analytical Laboratory, Smithsonian Institution, Washington, D.C.

Redman, Charles L.

1986 Qsar es-Seghir. Academic Press, New York.

Reitz, Elizabeth

1989 The Spanish Colonial Experience and Domestic Animals. Paper presented at the Annual Meeting of the Society for Historical Archaeology Conference on Historical and Underwater Archaeology, Baltimore, Maryland.

Sinopoli, CARla M.

n.d. The Blue on White Majolica of Qsar es-Seghir. Ms. on file, Department of Anthropology, University of Wisconsin, Milwaukee.

SKowroneK, RuSSELl K.

1989 Empire and Ceramics: Changing Indices of Commercial Strength. Paper presented at the Annual Meeting of the Society for Historical Archaeology Conference on Historical and Underwater Archaeology, Baltimore, Maryland.

SLUITER, ENGEL

1985 The Florida Situado: Quantifying the First Eighty Years, 1571-1651. Research Publications of the P.K. Younge Library of Florida History No. 1. University of Florida Libraries, Gainesville. 


\section{Solís, Carlos}

1988 Colonial Archaeology of San Juan de Puerto Rico: Excavations at the Casa Rosa Scarp Wall, San Juan National Historic Site, Puerto Rico. Report of Investigations 52. Prepared by Office of Archaeological Research, Alabama State Museum of Natural History, University of Alabama. University.

South, Stanley, Russell K. SKowronek, and

RICHARD E. JOHNSON

1988 Spanish Artifacts from Santa Elena. Anthropological Studies No. 7. South Carolina Institute of Archeology and Anthropology, University of South Carolina, Columbia.

\section{Thomas, David HuRst}

1988 Saints and Soldiers at Santa Catalina, Hispanic Designs for Colonial America. In The Recovery of Meaning. Historical Archaeology in the Eastern United States, edited by Mark P. Leone and Parker B. Potter, Jr., pp. 73-146. Smithsonian Institution Press, Washington, D.C.

1989 Alternative Designs for Colonial America: The View from Mission Santa Catalina, Georgia. Paper presented at the Annual Meeting of the Society for Historical Archaeology Conference on Historical and Underwater Archaeology, Baltimore, Maryland.

\section{J. EMLEN MYERS}

JACQUELINE S. OLIN

CONSERVATION ANALytical Laboratory

SMITHSONIAN INSTITUTION

WASHINGTON, D.C. 20560

Fernando de Amores Carredano

Departmento de ARQueología y PREHISTORIA

UNIVERSIDAD DE SEVILLA

41004 SeVILle, SPAIN
Alfonso Pleguezuelo Hernández
DEPARTMENTO DE ESCULTURA Y
Historia de las ARTes Plásticas
UNIVERSIDAD DE SEVILLA
41004 SeVille, SPAin 